\title{
Deactivation, Decontamination, and Decommissioning Project Summaries
}

\author{
D. Peterson
}

July 2001

Idaho National Engineering and Environmental Laboratory Bechtel BWXT Idaho, LLC 
INEEL/EXT-2000-01521

Revision 1

\title{
Deactivation, Decontamination and Decommissioning Project Summaries
}

\author{
D. Peterson \\ July 2001 \\ Idaho National Engineering and Environmental Laboratory \\ Environmental Restoration Directorate \\ Idaho Falls, Idaho 83415
}

\author{
Prepared for the \\ U.S. Department of Energy \\ Assistant Secretary for Environmental Restoration \\ Under DOE Idaho Operations Office \\ Contract DE-AC07-99ID13727
}




\section{SUMMARY}

This report is a compilation of summary descriptions of Deactivation, Decontamination and Decommissioning, and Surveillance and Maintenance projects planned for inactive facilities and sites at the INEEL from FY-2002 through FY-2010. Deactivations of contaminated facilities will produce safe and stable facilities requiring minimal surveillance and maintenance pending further decontamination and decommissioning. Decontamination and decommissioning actions remove contaminated facilities, thus eliminating long-term surveillance and maintenance. The projects are prioritized based on risk to DOE-ID, the public, and the environment, and the reduction of DOE-ID mortgage costs and liability at the INEEL. 


\section{CONTENTS}

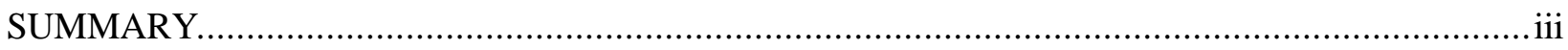

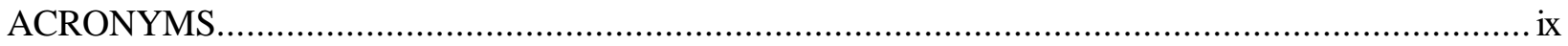

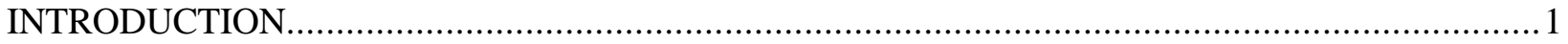

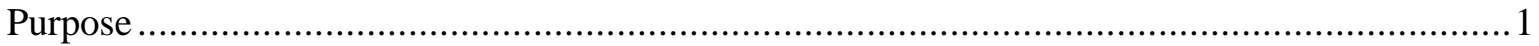

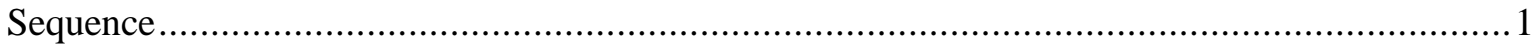

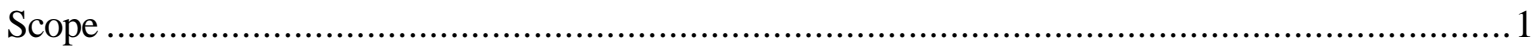

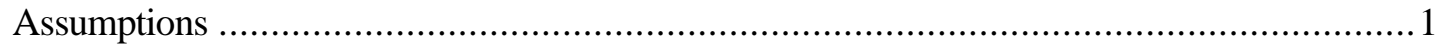

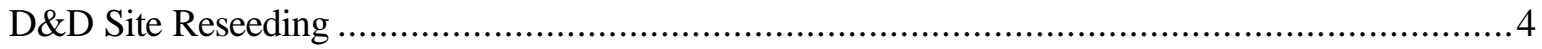

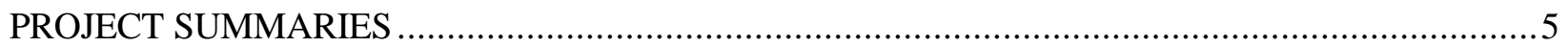

CFA-617 Laundry Decontamination Facility D\&D........................................................ 5

CPP-601 FUEL PROCESSING COMPLEX (FPC) DEACTIVATION/CLOSURE ............................6

CPP-603 Fuel Receipt and Storage Facility (FRSF) Basin Deactivation................................. 7

CPP-603 Fuel Receipt and Storage Facility (FRSF) D\&D/RCRA Closure............................. 8

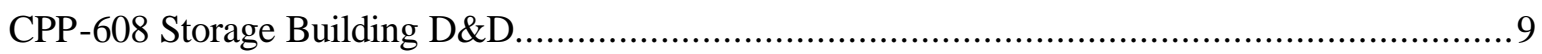

CPP-627/640/641 Fuel Processing Complex Deactivation.............................................. 10

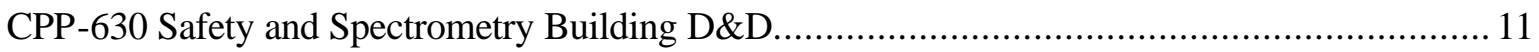

CPP-637 Process Improvement Facility Deactivation ...................................................... 12

CPP-648, -603 Basin Sludge Tank Control Deactivation................................................. 13

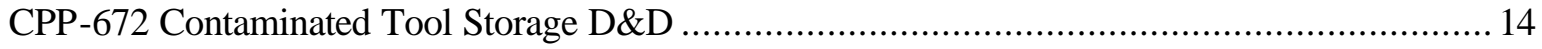

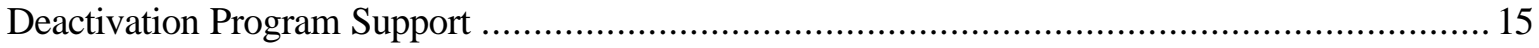

Decontamination and Dismantlement Program Support …............................................... 16

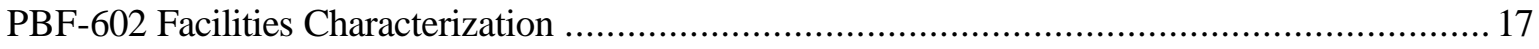

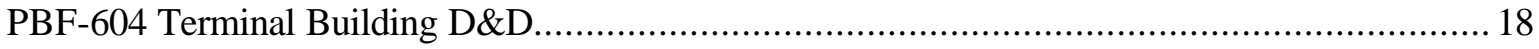

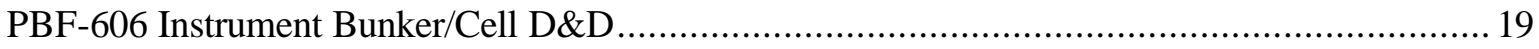

PBF-609 Special Power Excursion Reactor Test (SPERT) III Reactor Building

Waste Experimental Reduction Facility (WERF) Incinerator/RCRA Closure ........................... 20 


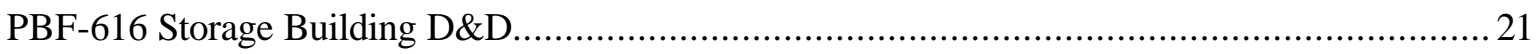

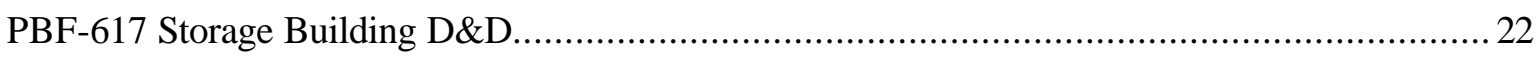

PBF-619 Control/Communications Building D\&D...................................................... 23

PBF-620 Reactor Canal/MTR-603 Canal Fuel Removal .................................................. 24

PBF-620 PBF Canal Water Removal Deactivation .......................................................... 25

PBF-620 Reactor Facility Characterization ............................................................... 26

PBF-621 Emergency Generator Building D\&D............................................................. 27

PBF-623 WERF Waste Storage Building D\&D............................................................ 28

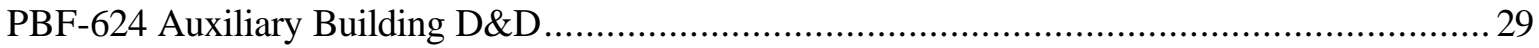

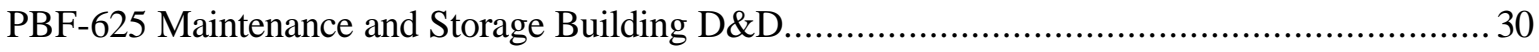

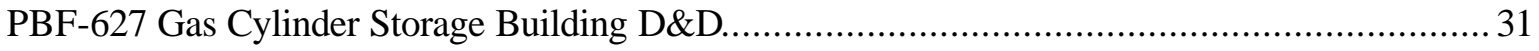

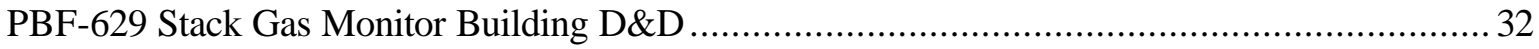

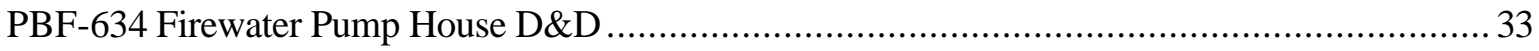

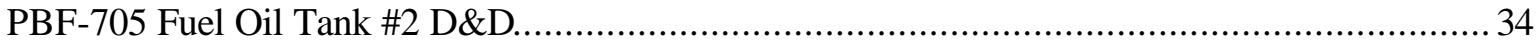

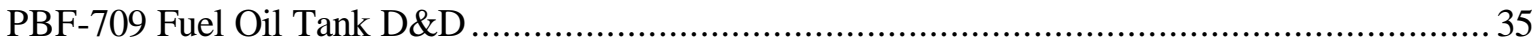

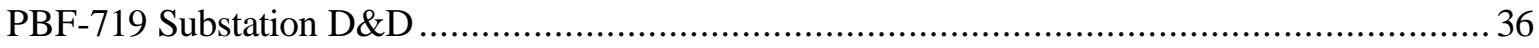

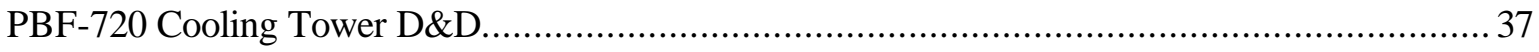

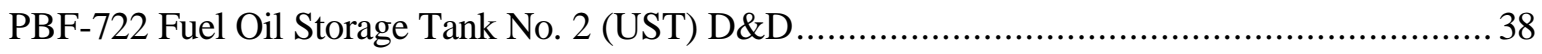

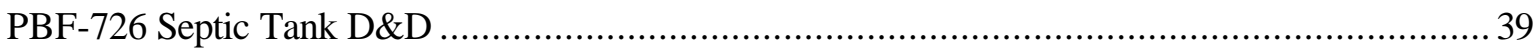

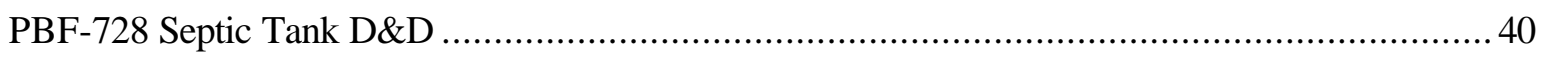

PBF-730 Primary Water Storage Tank D\&D.............................................................. 41

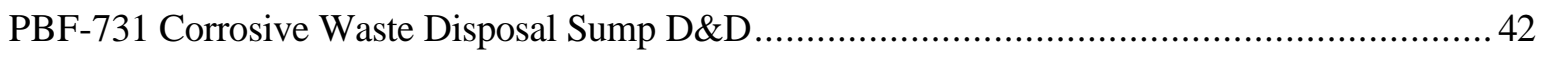

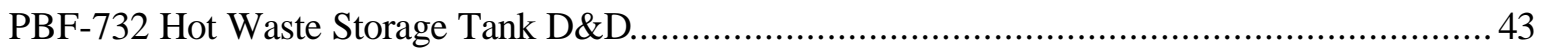

PBF-734 Fire \& Domestic Water Storage Tank D\&D .............................................. 44

PBF-761 Spray Dryer Absorber Structural Support D\&D ......................................... 45

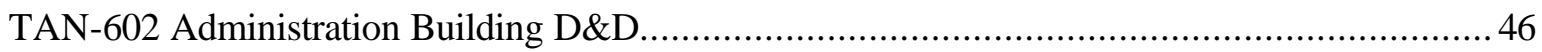


TAN-607, -734 Hot Shop Exhaust D\&D .................................................................. 47

TAN-607 Hot Shop Pool Deactivation......................................................................... 48

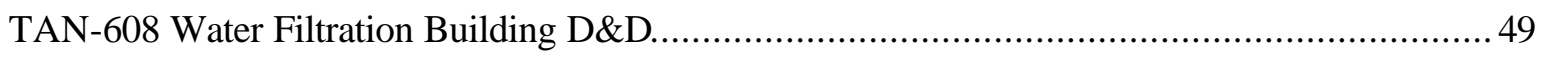

TAN-609 Equipment Maintenance Shop D\&D ......................................................... 50

TAN-615 Assembly \& Maintenance Facility D\&D .......................................................... 51

TAN-616 Liquid Waste Treatment Facility Characterization .............................................. 52

TAN-616 Liquid Waste Treatment Facility D\&D/RCRA Closure........................................... 53

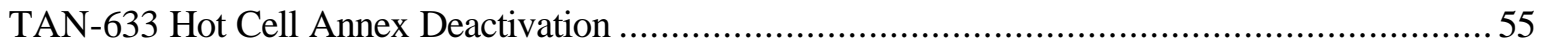

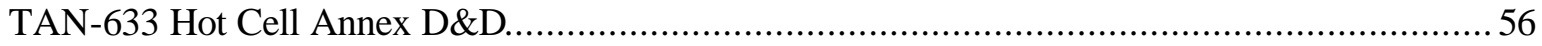

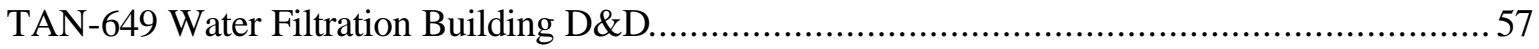

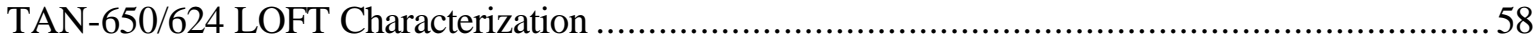

TAN-650/624 Containment Building (Loss-of-Fluid Test [LOFT] Facility) D\&D ..................... 59

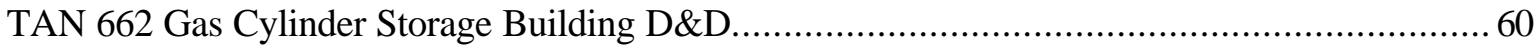

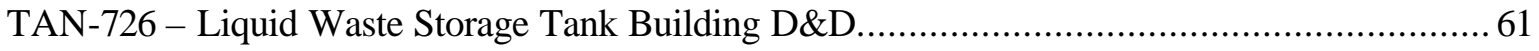

TRA-603 Material Test Reactor Canal Fuel Removal ................................................. 62

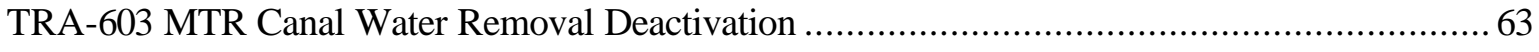

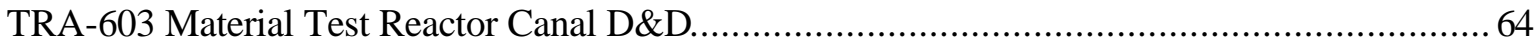

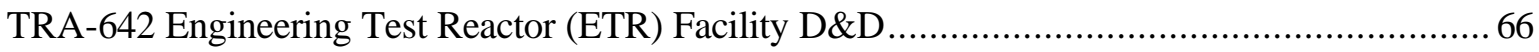

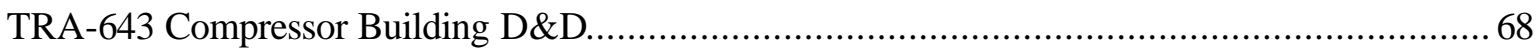

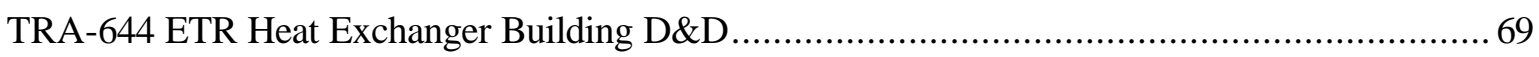

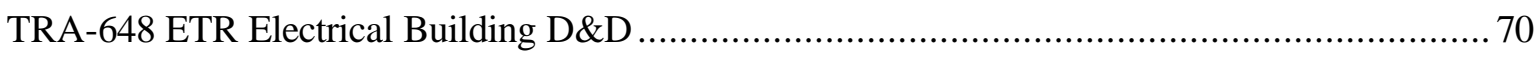

TRA-660 Advanced Reactivity Measurement Facility (ARMF) Decommissioning .................... 71

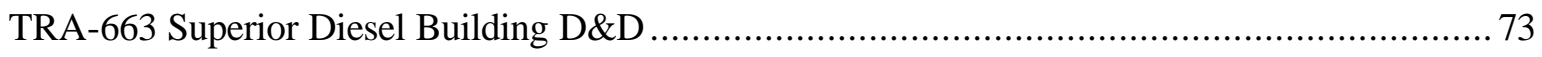

TRA-704 ETR Primary Filter Pits Characterization ................................................. 75

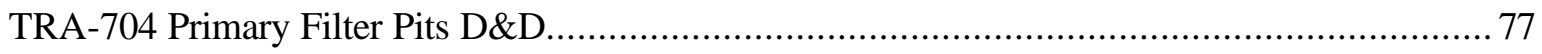

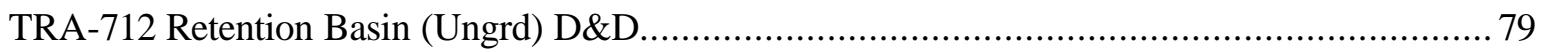


TRA-730-A, B, C, D Catch Tanks \#1, 2, 3, 4 Deactivation (UnGrd Hot Waste) ........................ 80

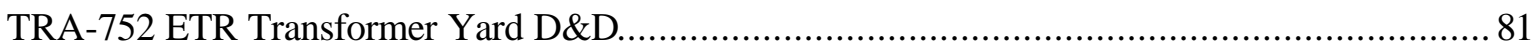

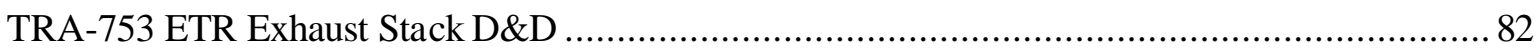

Annual INEEL S\&M-Non Defense Programs .............................................................. 83

Inactive Sites Project Surveillance and Maintenance Program............................................. 84

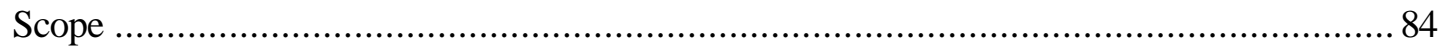

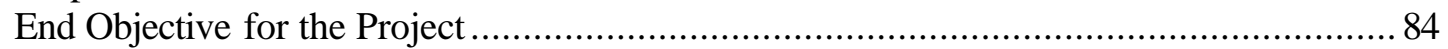

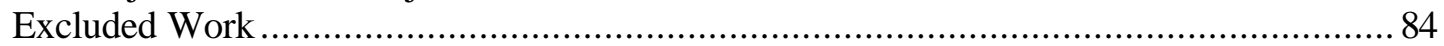

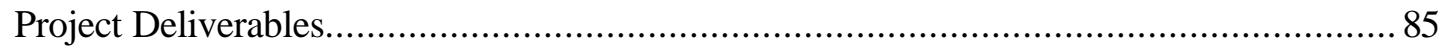

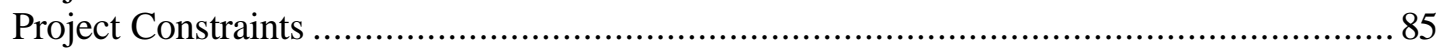

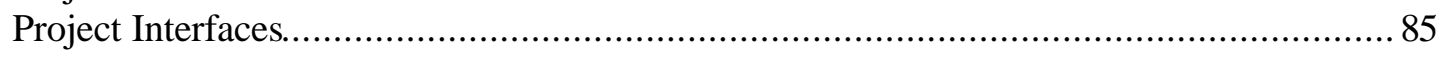

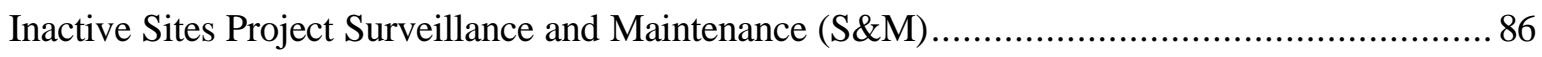

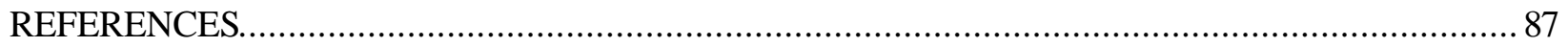

\section{FIGURES}

1. Deactivation, Decontamination, and Demolition ten year lookahead. 


\section{ACRONYMS}

\begin{tabular}{|c|c|}
\hline ARA & Auxiliary Reactor Area \\
\hline ARMF & Advanced Reactivity Measurement Facility \\
\hline BBWI & Bechtel BWXT Idaho, LLC \\
\hline CCR & competence commensurate with responsibility \\
\hline CERCLA & Comprehensive Environmental Response, Compensation, and Liability Act \\
\hline CFA & Central Facilities Area \\
\hline CFRMF & Coupled Fast Reactivity Measurement Facility \\
\hline D\&D & decontamination and decommissioning \\
\hline $\mathrm{D} \& \mathrm{D} \& \mathrm{D}$ & deactivation, decontamination, and decommission \\
\hline DOD & Department of Defense \\
\hline DOE & Department of Energy \\
\hline DOE-ID & Department of Energy Idaho Operations Office \\
\hline $\mathrm{EC} / \mathrm{CX}$ & environmental checklist/categorical exclusion \\
\hline EOCR & Experiment Organic Cooled Reactor \\
\hline ER & environmental restoration \\
\hline ETR & Engineering Test Reactor \\
\hline FDI & facility disposition initiative \\
\hline FM & facility manager \\
\hline FRSF & Fuel Receipt and Storage Facility \\
\hline FY & fiscal year \\
\hline GEEL & General Electric Experimental Loop \\
\hline HASP & health and safety plan \\
\hline IDHW & Idaho Department of Health and Welfare \\
\hline IDW & investigation-derived waste \\
\hline IET & Initial Engine Test \\
\hline
\end{tabular}




\begin{tabular}{|c|c|}
\hline INEEL & Idaho National Engineering and Environmental Laboratory \\
\hline INTEC & Idaho Nuclear Technology Engineering Center \\
\hline IPABS & integrated planning, accountability, and budgeting system \\
\hline IRC & independent review committee \\
\hline ISM & integrated safety management \\
\hline LOFT & Loss-of-Fluid Test \\
\hline MTR & Material Test Reactor \\
\hline NEPA & National Environmental Policy Act of 1969 \\
\hline NMIS & Nuclear Materials Inspection and Storage \\
\hline OMRE & Organic Moderated Reactor Experiment \\
\hline ORPS & occurrence reporting and processing system \\
\hline ORR & operational readiness review \\
\hline PBF & Power Burst Facility \\
\hline PBS & project baseline summary \\
\hline PREPP & Process Experimental Pilot Plant \\
\hline RCRA & Resource Conservation and Recovery Act \\
\hline ROM & Rough Order of Magnitude \\
\hline SAP & sample analysis plan \\
\hline $\mathrm{S} \& \mathrm{M}$ & surveillance and maintenance \\
\hline SNF & spent nuclear fuel \\
\hline SPERT & Special Power Excursion Reactor Test \\
\hline SRT & special response team \\
\hline STF & security training facility \\
\hline TAA & temporary accumulation area \\
\hline TAN & Test Area North \\
\hline TBD & to be determined \\
\hline
\end{tabular}


TRA Test Reactor Area

TRU transuranic

VCO voluntary consent order

WERF Waste Experimental Reduction Facility

WIPP Waste Isolation Pilot Plant 


\title{
Deactivation, Decontamination and Decommissioning Project Summaries \\ INTRODUCTION
}

\author{
Purpose
}

This Deactivation, Decontamination and Decommissioning (D\&D\&D) report presents summary project descriptions alphabetized by facility/activity name. The D\&D\&D prioritization (see Figure 1) lists the project budget planning at the Project Baseline Summary (PBS) level by priority from FY-2002 through FY-2007.

\section{Sequence}

The sequence of planned projects for FY-2002 through FY-2010, is identified by the risk-weighted priority numbers assigned to each project summary. The project PBSs (see Figure 1) reflect the most current estimates of budget planning and will be the basis for upcoming funding requests.

\section{Scope}

The project summaries include: date, name, priority, scope, related actions, location, point of contact, milestones, issues, project-specific assumptions, and cost and schedule.

\section{Assumptions}

The following assumptions support the planned project performance by the priority listed:

- $\quad$ Completion of basin floors scans by December 2001, at the Idaho Nuclear Technology Engineering Center INTEC)-603

- $\quad$ Removal of SNF stored in Material Test Reactor (MTR) Canal by end of FY-2003

- $\quad$ Removal of Power Burst Facility ( PBF) Reactor fuel by end of FY-2004

- $\quad$ Project completion without significant increase in rigor of regulatory compliance

- $\quad$ Continued management of Idaho National Engineering and Environmental Laboratory (INEEL) inactive sites as prescribed by Department of Energy (DOE) 430.1A Life Cycle Asset Management

- $\quad$ Facility end-states compatible with contemporary D\&D\&D technology applications

- $\quad$ Facility turnover to D\&D\&D completed as planned

- Continued on-site disposal of LLW and Industrial waste

- $\quad$ Continued access to TSD capability for disposition of HW and MW

- Continued application of technology developments proven by demonstration

- $\quad$ Authorized funding levels will support project performance by priority as listed by the project funding lookahead (see Figure 1).

- $\quad$ No funding impact by the current moratorium on the free release of scrap metals. 
DECONTAMINATION \& DEMOLITION

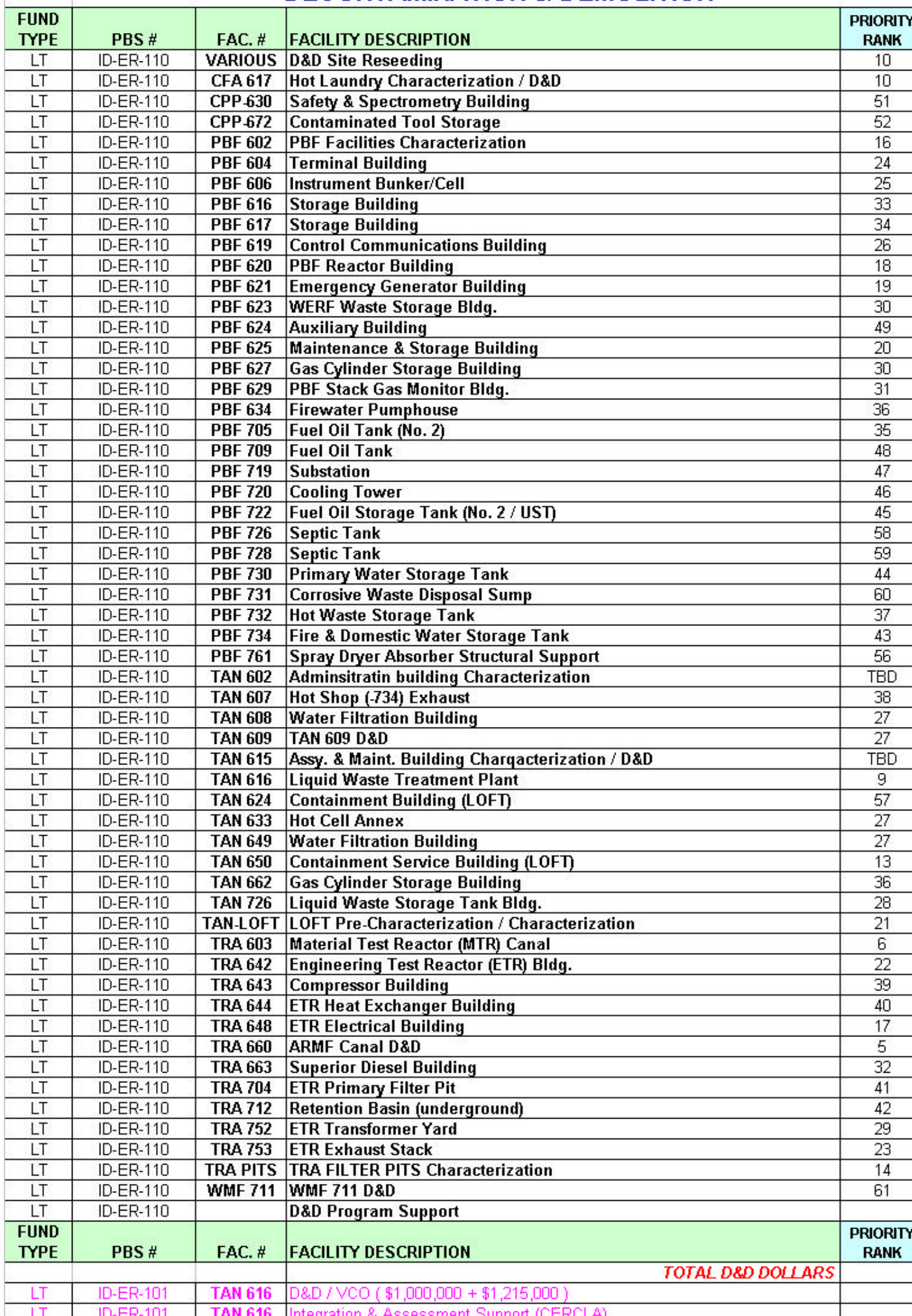

PROJECT SUMMARY INEEL / (EXT - 2000 - 01521, REVISION 1)

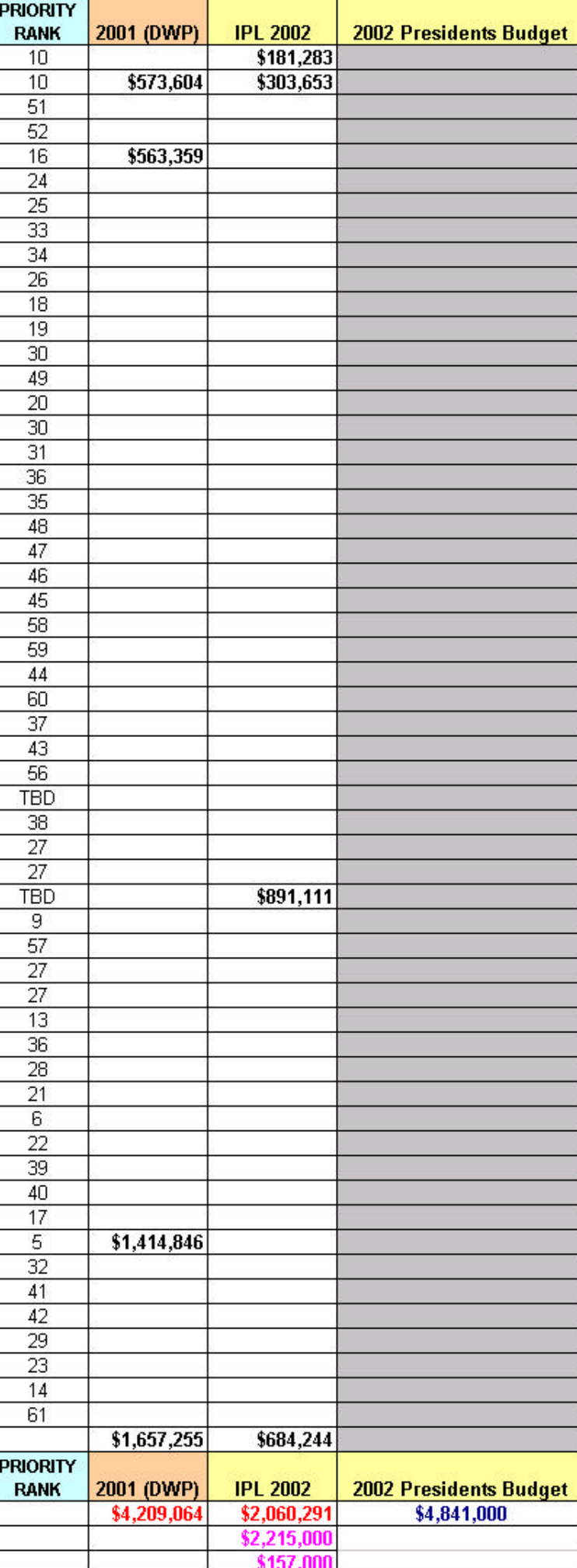

\begin{tabular}{|c|c|c|c|c|c|c|c|c|c|}
\hline 2003 & 2004 & 2005 & 2006 & 2007 & 2008 & 2009 & 2010 & 2011 & 2012 \\
\hline$\$ 1,180,204$ & & & & & & & & & \\
\hline & & & & & & 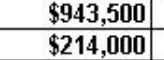 & $\$ 943,500$ & & \\
\hline & & & $\$ 502,358$ & $\$ 502,358$ & $\begin{array}{l}\$ 502,358 \\
\$ 198000\end{array}$ & & & & \\
\hline & & & & & & $\$ 239,000$ & & & \\
\hline & & & & & & & $\begin{array}{l}\$ 174,000 \\
\$ 71,000\end{array}$ & & \\
\hline & & & & & $\begin{array}{r}\$ 806,000 \\
18,058,847\end{array}$ & $\$ 1,058,47$ & $\$ 1,058,417$ & & \\
\hline & & & & & & $\begin{array}{r}\$ 131,000 \\
\$ 4720\end{array}$ & 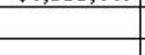 & & \\
\hline & & & & & $\$ 191,000$ & & & & \\
\hline & & & & & $\$ 274,000$ & \begin{tabular}{|}
$\$ 408,000$ \\
$\$ \$ 1709000$
\end{tabular} & & & \\
\hline & & & & & \begin{tabular}{|c|c|}
$\$ 90,000$ \\
\end{tabular} & & & & \\
\hline & & & & & & & $\$ \frac{\$ 221,000}{\$ 112,000}$ & & \\
\hline & & & & & & & $\begin{array}{l}\$ 84,000 \\
\$ 143000\end{array}$ & & \\
\hline & & & & & & & $\$ 173,000$ & & \\
\hline & & & & & & & $\$$ & & \\
\hline & & & & & $\$ 85,000$ & & 322,000 & & \\
\hline & & & & & & & 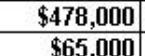 & & \\
\hline & & & & & & & $\$ 597,000$ & & \\
\hline & & & & & & $32,047,000$ & $\$ 200,000$ & & \\
\hline$\$ 350,430$ & $\$ 1,338,400$ & & & & $\$ 1,000,000$ & $\$ 4,000,000$ & $\$ 6,000,000$ & & \\
\hline & 6490,620 & 8749 380 & & - & $\$ 94,000$ & & & & \\
\hline $\begin{array}{l}\$ 76,539 \\
\end{array}$ & & & & & & & & & \\
\hline & $\$ 1,928,667$ & & & & & & $\$ 1.122$ ת & & \\
\hline & & & & & $\$ 2,185,000$ & & $0,1<2,000$ & & \\
\hline & & & & $\mathbf{\$ 4 5 8 . 6 4 0}$ & $\$ 102,000$ & & & & \\
\hline & & & & & $\$ 1553500$ & $\$ 1512501$ & $\$ 708,333$ & & \\
\hline & & & $\begin{array}{l}8500,474 \\
\end{array}$ & $\$ 500,474$ & & & & & \\
\hline & & $\$ 567,000$ & & & $\$ 1,120,000$ & $\$ 1,465,803$ & $\$ 2,558,154$ & $\$ 2,518,154$ & $\$ 2,518,154$ \\
\hline & & & & & $\$ 1,003,667$ & $\$ 1,003,667$ & $\$ 1,003,667$ & & \\
\hline & & $\$ 481,750$ & $\$ 481,750$ & & 9861,667 & $\$ 861,667$ & $\$ 861,667$ & & \\
\hline & & & $\$ 498001$ & & & & & & \\
\hline & & & & & $\$ 1,070,000$ & & & & \\
\hline & & & & & $\$ 285,000$ & & $\$ 1,157,500$ & $\$ 1,157,500$ & \\
\hline & & & & & $\$ 1,458,333$ & $\$ 1,458,333$ & & & \\
\hline & & & & $\$ 213,000$ & $\$ 850,803$ & $\$ 243152$ & & & \\
\hline$\$ 767,573$ & $\$ 7998,016$ & $\begin{array}{c}8837,917 \\
\end{array}$ & $\$ 879,813$ & $\begin{array}{l}\$ 923,803 \\
\end{array}$ & $\$ 969,993$ & $\$ 1,018,493$ & $\$ 1,069,418$ & $\$ 1,660,000$ & $\$ 1,660,000$ \\
\hline & 2004 & 2005 & & 2007 & 2008 & 2009 & 2010 & 2011 & 2012 \\
\hline$\$ 2,554,746$ & $\$ 2,627,036$ & $\$ 2,636,047$ & $\$ 2,562,395$ & $\$ 2,598,275$ & $\$ 15,730,737$ & $\$ 18,672,531$ & $\$ 19,322,655$ & $\$ 5,335,654$ & $\$ 4,178,154$ \\
\hline
\end{tabular}

Figure 1. Deactivation, Decontamination, and Demolition ten year lookahead. 


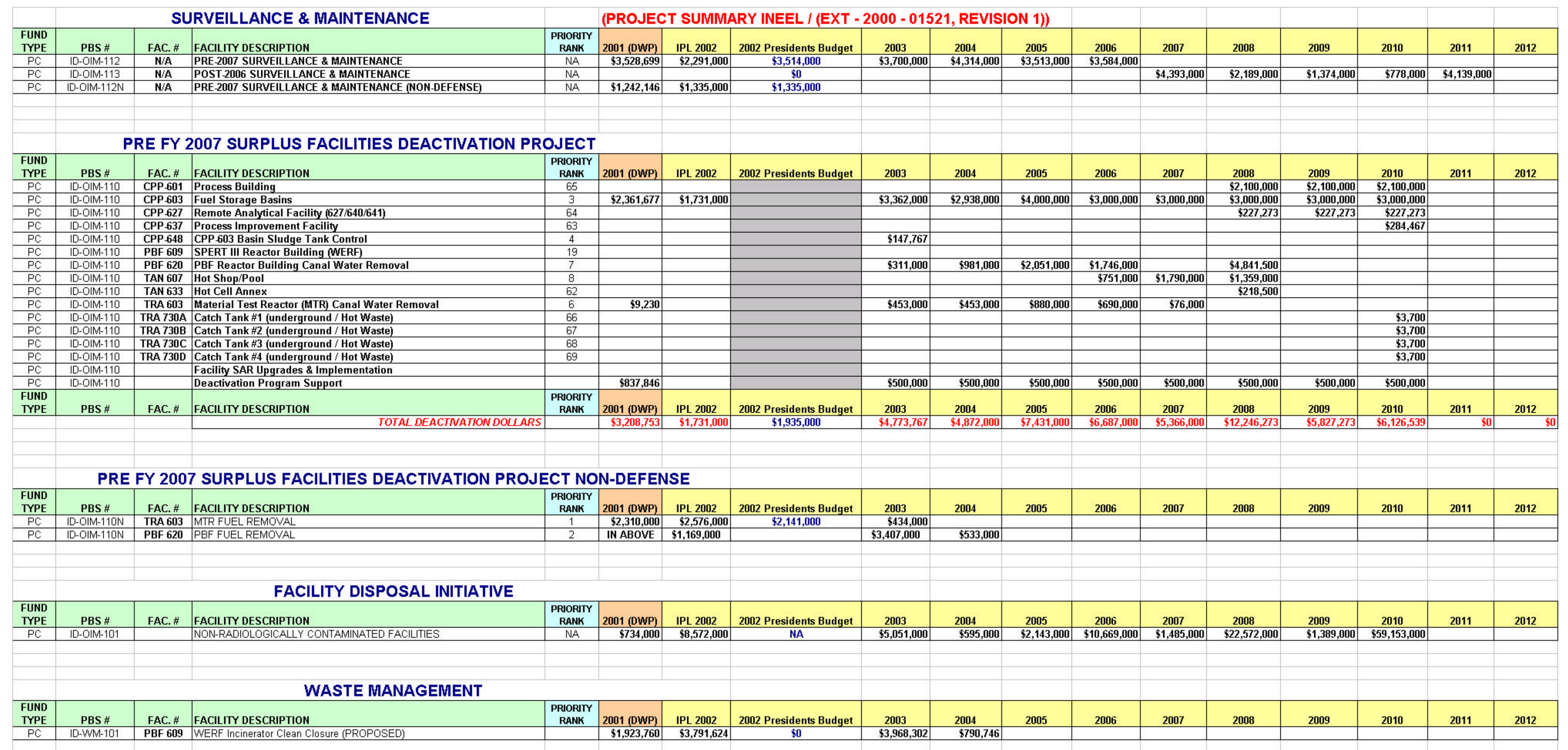

Figure 1 (continued). Deactivation, Decontamination, and Demolition ten year lookahead. 


\section{D\&D Site Reseeding}

Date: $\quad$ July 17,2001

Priority: $\quad$ TBD

Scope: $\quad$ Effect soil stabilization and revegetation at the following D\&D sites:

- $\quad$ TAN/IET-620/656

- $\quad$ ARVFS Bunker

- $\quad$ CFA-691 Sewage Treatment Plant

- $\quad$ CFA-678/679

- $\quad$ STF-601 Security Training Facility

- $\quad$ FS \# 2 Fire Station ${ }^{\#} 2$ - Training Installation.

Related Actions : $\quad$ None

Location: $\quad$ INEEL

Point of Contact: $\quad$ F. L. Webber, D\&D\&D Project Manager, 526-8507

Milestones: $\quad$ Startup: $10 / 1 / 01 \quad$ Completion: $9 / 30 / 02$

Issues: $\quad$ None

Assumptions : $\quad$ None

Cost and Schedule : $\quad \$ 181,283$

Background: $\quad$ None

Justification for D\&D: Reseeding is necessary to stabilize and revegetate the disturbed land areas and therefore restore the sites to conditions consistent with their surrounding lands. 


\section{PROJECT SUMMARIES \\ CFA-617 Laundry Decontamination Facility D\&D}

Date: $\quad$ July 17,2001

Priority: $\quad 10$ (On-hold pending funding).

Scope: $\quad$ This D\&D project initially planned as a decommissioning, will demolish and remove the Central Facilities Area (CFA)-617 Laundry Decontamination Facility. This project has removed and disposed or excessed the laundry and respirator equipment, and the radiologically contaminated facility remains awaiting further decontamination and demolition, and disposal.

Related Actions: $\quad$ None

Location: $\quad$ North area of Central Facilities Area (CFA)

Point of Contact: $\quad$ F. L. Webber, D\&D\&D Project Manager, 526-8507

Milestones: $\quad$ Startup: 10/1/01 Completion: $9 / 30 / 03$

Issues: $\quad$ Radiological contamination has been found outside controlled buffer areas.

Assumptions :

Cost and Schedule: Estimated to be $\$ 1.5$ Million,

FY-02 Characterization $\$ 303,653$

FY-03 D\&D \$1,180,204

Background: $\quad$ The CFA-617 facility was built in 1981 and operated for several years as the cleaning facility for radiologically contaminated laundry and respirators. In the mid 1980s this facility was shut down. Because of radiological contamination, it has been left in an inactive state.

Justification for D\&D: While the risk of radiological release from this facility is very low, its demolition and removal is more cost-effective than upgrading for some reuse. 


\section{CPP-601 FUEL PROCESSING COMPLEX (FPC) DEACTIVATION/CLOSURE}

Date: $\quad$ July 17, 2001

Priority: $\quad 65$

Scope: $\quad$ The anticipated Deactivation/closure will include some decontamination and removal of hazardous wastes followed by the in-place immobilization and grout encapsulation of the below grade structure and system components followed by isolation of the entire facility system in anticipation of the D\&D

Related Actions : $\quad$ D\&D\&D of the adjoining CPP-602, -630, -627, -640, and -641

Location: $\quad$ INTEC

Point of Contact: $\quad$ F. L. Webber, D\&D\&D Project Manager, 526-8507

Milestones: $\quad$ FY-08 $\quad$ Completion: TBD

Issues: $\quad$ Approved Regulatory pathway for anticipated project scope.

Assumptions: $\quad$ TBD

Cost and Schedule : $\quad$ Estimated cost \$2.1 million/yr (FY-08-09-10)

Completion: TBD

Background: $\quad$ The CPP-601 FPC is a very heavily reinforced concrete structure with 4 levels below grade and 1 level above grade built in 1953, and totaling about $58,000 \mathrm{ft}^{2}$. The facility system provided a shielded remote operated process system for the recovery of uranium from spent nuclear fuel (SNF). With the end of uranium recovery operations in 1992, the facility system has experienced extensive flushing and clean-out with limited operation of its ventilation system and some RCRA waste storage tanks. The contaminated facility is now under surveillance and maintenance $(\mathrm{S} \& \mathrm{M})$ while awaiting deactivation followed by $\mathrm{D} \& \mathrm{D}$.

Justification for D\&D: The deactivation is necessary to eliminate facility hazards and waste streams posting potential health and safety risks to personnel and the environment. Implementing the required mitigation also reduces DOE-ID mortgage costs and liability. 


\section{CPP-603 Fuel Receipt and Storage Facility (FRSF) Basin Deactivation}

Date:

Priority:

Scope :

$\underline{\text { Related Actions }}$

Location:

Point of Contact:

Milestones:

Issues:

Assumptions :
July 17, 2001

\section{3}

The deactivation as currently planned will utilize natural evaporation over an eight year period. Grout will be added to match the loss of water level from evaporation. The evaporation and grout filling will start upon removal of the basin sludge and completion of the NEPA process. RCRA closure of water treatment units will also be completed.

Completion of the facility D\&D

INTEC

Lenny Weidert, Project Engineer, 526-3142 or 526-4903

Deactivation Startup: 10/01/00 Completion: 9/30/10

Buy-in by DOE-ID, Bechtel BWXT Idaho, LLC (BBWI), and agencies for the disposition and long-term management of the sludge as an "accountable material," with the final end-state of the facility, as back-filled (grout), and capped. Most of the FY-02 funding for deactivation was cut in order to get the EM budget down to target funding levels.

The preferred alternative in the Environmental Assessment of natural evaporation is approved. No fuel pieces will be discovered during the basin scans.

Cost and Schedule : $\quad$ \$29.3M (ROM) through FY-2010

Background:

The CPP-603 FRSF has three water filled Spent Nuclear Fuel (SNF) storage basins from which the SNF has been removed.

Justification for Deactivation: Facility deterioration over time endangers the structural integrity required to contain the basin water. The basins contain 1,500,000 gallons of radiologically contaminated water. 


\section{CPP-603 Fuel Receipt and Storage Facility (FRSF) D\&D/RCRA Closure}

Date:

Priority:

Scope :

Related Actions:

Location:

Point of Contact:

Milestones:

Issues:

Assumptions :

Cost and Schedule : $\quad$ Estimated cost \$8.15 M (FY-99 \$s).

Background:

July 17,2001

3

FRSF Basin Deactivation

INTEC closure.

See Closure Pla n
Following completion of the D\&D/RCRA closure, the remaining facility structures will be demolished and disposed as required. Following will be the installation of a cap over the basin half of the facility. The dry-storage hotcell side of the facility will remain in service.

F. L. Webber, D\&D\&D Project manager, 526-8507

Startup: 10/01/10 Completion: TBD

Determination and approval of proposed path forward for D\&D as a landfill type

The CPP-603 FRSF is a heavily reinforced concrete structure of about 12,400 $\mathrm{ft}^{2}$ built in 1953 . The facility houses spent nuclear fuel by dry storage in a larger hotcell, and by wet storage in three large water-filled basins totaling about 1.5 million gal. The SNF has been removed from the storage basin.

Justification for D\&D: $D \& D$ is necessary to eliminate facility hazards and waste streams posing potential health and safety risks to personnel and the environment. Implementing required mitigations also reduces DOE-ID mortgage costs and liability. 


\section{CPP-608 Storage Building D\&D}

Date: $\quad$ July 17,2001

Project Name: $\quad$ CPP-608 Storage Building D\&D

Priority: $\quad 53$

Scope: $\quad$ Decontamination, demolition and disposal with limited materials recycling.

Related Actions : $\quad$ TBD

Location: $\quad$ INTEC

Point of Contact: $\quad$ F. L. Webber, D\&D\&D Project Manager, 526-8507

Milestones: $\quad$ Startup: 10/01/07 Completion: 9/30/08

Issues: $\quad$ TBD

Assumptions: $\quad$ TBD

Cost and Schedule : Estimated Cost $-\$ 271 \mathrm{~K}$

Background: $\quad$ CPP-608 is a small steel building at about $2,600 \mathrm{ft}^{2}$ built in 1953 . The now inactive facility provided storage for rad contaminated components, items, and various potentially hazardous materials.

Justification for D\&D: D\&D is necessary to eliminate facility hazards and waste streams posing potential health and safety risks to personnel and the environment. Implementing required mitigations also reduces DOE-ID mortgage costs and liability. 


\section{CPP-627/640/641 Fuel Processing Complex Deactivation}

Date: $\quad$ July 17,2001

Priority: $\quad 64$

Scope: $\quad$ The project is driven by risk reduction, mortgage reduction and compliance agreements for Resource Conservation and Recovery Act (RCRA) closure of the low-level liquid waste tank sampling, storage, and transfer system. In addition, this activity will reduce the time this facility will require monitoring, thereby reducing the S\&M costs and the risk of release of contaminated materials to the environment.

Related Actions: $\quad$ TBD

Location: $\quad$ CPP-627/640/641

Point of Contact: $\quad$ F. L. Webber, D\&D\&D, Project Manager, 526-8507

Milestones: $\quad$ Startup: FY-08 $\quad$ Completion: TBD

Issues: $\quad$ Project pushed to out-years due to funding constraints.

Assumptions: $\quad$ TBD

Cost and Schedule: $\quad$ The cost estimate (ROM) for completion totals $\$ 28.1 \mathrm{M}(\mathrm{CPP}-627, \$ 2.5 \mathrm{M}$; CPP-640, \$4.5M; CPP-601, \$21.0M).

Background: $\quad$ TBD

Justification for Deactivation: Deactivation is necessary to establish and maintain safe and stable facility conditions to significantly reduce S\&M liability and cost while awaiting D\&D. 


\section{CPP-630 Safety and Spectrometry Building D\&D}

Date: $\quad$ July 17,2001

Priority: $\quad 51$

Scope: $\quad$ The D\&D will include decontamination and disposal of various hazardous wastes and rad waste, followed by demolition and disposal of the remaining structure.

Related Actions : $\quad$ Deactivation of adjoining CPP-601 and -602.

Location: $\quad$ CPP 630

Point of Contact: $\quad$ F. L. Webber, D\&D\&D Project Manager, 526-8507

Milestones: $\quad$ Startup: 10/1/08 Completion: $9 / 30 / 10$

Issues: $\quad$ TBD

Assumptions: $\quad$ TBD

Cost and Schedule : $\quad$ Estimated Cost - \$1.89M (ROM)

Background: $\quad$ The CPP-630 is a multistory facility of masonry construction over about $13,000 \mathrm{ft}^{2}$, built in 1956. The facility provides several laboratories and office space.

Justification for D\&D: D\&D is necessary to eliminate facility hazards and waste streams posing potential health and safety risks to personnel and the environment. Implementing required mitigations also reduces DOE-ID mortgage costs and liability. 


\section{CPP-637 Process Improvement Facility Deactivation}

Date: $\quad$ July 17,2001

Priority: $\quad 63$

Scope: $\quad$ The deactivation is anticipated to decontaminate and remove various hazardous wastes in preparation for D\&D.

Related Actions: $\quad$ TBD

Location: $\quad$ INTEC

Point of Contact: $\quad$ F. L. Webber, D\&D\&D Project Manager, 526-8507

Milestones: $\quad$ Startup: 10/01/09 Completion: 09/30/10

Issues: $\quad$ TBD

Assumptions: $\quad$ TBD

Cost and Schedule : Estimated Cost - \$285K

Background: $\quad$ The CPP-637 facility is of masonry construction over about $33,000 \mathrm{ft}^{2}$, built in 1959. The facility provides various laboratories for $R \& D$ and demonstration mockup operations, and the supporting office space.

Justification for Deactivation: Deactivation is necessary to establish and maintain safe and stable facility conditions to significantly reduce S\&M liability and cost while awaiting D\&D. 


\section{CPP-648, -603 Basin Sludge Tank Control Deactivation}

Date: $\quad$ July 17,2001

Priority: $\quad 4$

Scope: $\quad$ Decontamination, equipment/component removal, and stabilization pending D\&D.

Related Actions: $\quad$ TBD

Location: $\quad$ CPP 648

Point of Contact: $\quad$ F. L. Webber, D\&D\&D Project Manager, 526-8507

Milestones: $\quad$ Startup: $10 / 1 / 02$ Completion: $9 / 30 / 03$

Issues: $\quad$ TBD

Assumptions: $\quad$ TBD

Cost and Schedule : Estimated Cost $(\$ 148 \mathrm{~K})$ - Presently, this task will be accomplished as part of the INTEC-CPP-603 Basin Deactivation (see page 7).

Background: $\quad$ CPP-648 at about $500 \mathrm{ft}^{2}$ houses, since 1973, a process system for control of the basin sludge tank. Deactivation of the now inactive facility system will be part of the CPP-603 deactivation.

Justification for D\&D: D\&D is necessary to eliminate facility hazards and waste streams posing potential health and safety risks to personnel and the environment. Implementing required mitigations also reduces DOE-ID mortgage costs and liability. 


\section{CPP-672 Contaminated Tool Storage D\&D}

Date: $\quad$ July 17,2001

Priority: $\quad 52$

Scope: $\quad$ Decontamination, demolition, and disposal as LLW.

Related Actions : $\quad$ TBD

Location: $\quad$ CPP-672

Point of Contact: $\quad$ F. L. Webber, D\&D\&D Project Manager, 526-8507

Milestones: $\quad$ Startup: 10/1/08 Completion: 9/30/09

Issues: $\quad$ TBD

Assumptions: $\quad$ TBD

Cost and Schedule : $\quad$ Estimated Cost $-\$ 214 \mathrm{~K}(\mathrm{ROM})$

Background: $\quad$ CPPO-672 of steel construction built in 1981, provides about $1,000 \mathrm{ft}^{2}$ of storage space for contaminated tools suitable for continued use on contaminated equipment.

Justification for D\&D: D\&D is necessary to eliminate facility hazards and waste streams posing potential health and safety risks to personnel and the environment. Implementing required mitigations also reduces DOE-ID mortgage costs and liability. 


\section{Deactivation Program Support}

Date: $\quad$ July 17,2001

Priority: $\quad$ Annual Programmatic need

Scope: $\quad$ Develop current and outyear planning for deactivation program. Use this planning in the development of PBS, Life Cycle Planning, and integrated planning, accountability, and budgeting system (IPABS) input. Integrate Facility Disposition Initiative (FDI), D\&D, and deactivation planning into a single schedule based upon prioritization for all inactive INEEL facilities. Develop life cycle plans for all inactive INEEL sites.

Related Actions: $\quad$ None

Location: $\quad$ Office Support Function

Point of Contact: $\quad$ F. L. Webber, Project Manager, Program Development, 526-8507

Milestones: $\quad$ Startup: FY2000 Completion: FY2045

Issues: $\quad$ None

Assumptions: $\quad$ Annual activity

Cost and Schedule: $\quad$ Deactivation Program Support is planned at $\$ 837,846 / \mathrm{FY}-02$ and at $\$ 500 \mathrm{~K} / \mathrm{yr}$ for FY-03 through

FY-10.

Background: $\quad$ N.A.

Justification for Support: This activity provides programmatic support to maintain management, administrative, and development needs not specific to a single project, and therefore, not part of a facility/site specific project baseline. 


\section{Decontamination and Dismantlement Program Support}

Date:

Priority:

Scope :

Related Actions :

Location:

Point of Contact:

Milestones:

Issues:

Assumptions :

Cost and Schedule :

Background:
July 17,2001

Annual Programmatic Need

Support current year and outyear planning for D\&D program development inclu ding PBS, Life Cycle, and IPABS documentation. Support integration of FDI, D\&D and deactivation activities into a single program plan reflecting scope, cost, schedule, and priority for inactive INEEL facilities. Support preventative maintenance implementation for a fleet (80 plus items) of D\&D equipment required for project completion. Maintain program procedures, practices, and guides to ensure the timely resolution of issues, audits, self-assessments, and corrective actions, and the timely completion of customer-driven special assignments. Coordinate personnel training needs specific to integrated safety management/competence commensurate with responsibility (ISM/CCR) compliance.

Program/budget change controls, self-assessments, safety ins pections, ICARE corrective actions, Occurrence Reporting and Processing System (ORPS) analysis and resolution, regulatory inspections, ISM/CCR, IWCP, STD-101, MCP-3562 HIM. Conduct of maintenance, Conduct of Operations, utility isolations, property management, record retention, project documentation, procedure maintenance, and status reporting.

Office support function

F. L. Webber, D\&D\&D Project Manager, 526-8507

Startup: FY-1992 Duration through FY-2006 by baseline

None

Customer funding authorization continues; therefore, D\&D program projects continue; therefore need for D\&D program support continues.

D\&D program support is planned at $\$ 684,244 / \mathrm{FY}-02$ and escalating to $\$ 1,069,418 / \mathrm{FY}-10$.

This support activity has been in place since FY-92.

Justification for Support: This activity provides programmatic support required to maintain management, administrative, and development needs not specific to a single project, and therefore, not part of a facility/site specific project baseline. 


\section{PBF-602 Facilities Characterization}

Date: $\quad$ July 17,2001

Priority: $\quad 16$

Scope: $\quad$ The characterization will target materials with hazardous waste potential and facility makeup presenting potential health and safety risks specific to D\&D application.

Related Actions : $\quad$ TBD

Location: $\quad$ PBF

Point of Contact: $\quad$ F. L. Webber, D\&D\&D Project Manager, 526-8507

Milestones: $\quad$ Startup: FY-06 Completion: FY-08

Issues: $\quad$ TBD

Assumptions: $\quad$ TBD

Cost and Schedule : $\quad \$ 1.51 \mathrm{M}$

Background: $\quad$ This effort will address several small facilities built in the 1950s and 1960s.

Justification for D\&D: To determine facility hazards and waste streams posing health and safety risks to personnel exposure and release to the environment. Facilitate definition of mitigation required to eliminate risk. 


\section{PBF-604 Terminal Building D\&D}

Date: $\quad$ July 17,2001

Priority: $\quad 24$

Scope: $\quad$ Decontamination, demolition, and disposal as LLW.

Related Actions : $\quad$ TBD

Location: $\quad$ PBF 604

Point of Contact: $\quad$ F. L. Webber, D\&D\&D Project Manager, 526-8507

Milestones: $\quad$ Startup: FY-08 Completion: FY-08

Issues: $\quad$ TBD

Assumptions: $\quad$ TBD

Cost and Schedule : $\quad$ Estimated Cost $-\$ 180 \mathrm{~K}(\mathrm{ROM})$

Background: $\quad$ PBF-604, built in 1955 of steel construction over $610 \mathrm{ft}^{2}$, provided a terminal connection area for test utilities. The now inactive facility is rad contamination hazard.

Justification for D\&D: D\&D is necessary to eliminate facility hazards and waste streams posing potential health and safety risks to personnel and the environment. Implementing required mitigations also reduces DOE-ID mortgage costs and liability. 


\section{PBF-606 Instrument Bunker/Cell D\&D}

Date: $\quad$ July 17,2001

Priority: $\quad 25$

Scope: $\quad$ Decontamination, demolition, and disposal

Related Actions : $\quad$ TBD

Location: $\quad$ PBF 606

Point of Contact: $\quad$ F. L. Webber, D\&D\&D Project Manager, 526-8507

Milestones: $\quad$ Startup: FY-09 Completion: FY-09

Issues: $\quad$ TBD

Assumptions : $\quad$ TBD

Cost and Schedule : $\quad$ Estimated Cost $-\$ 239 \mathrm{~K}(\mathrm{ROM})$

Background: $\quad$ PBF-606, built in 1955 of masonry construction over $230 \mathrm{ft}^{2}$, housed instrumentation specific to experimental operations.

Justification for D\&D: D\&D is necessary to define facility hazards and waste streams posing health and safety risks to personnel and the environment and to implement required mitigations thus reducing DOE-ID mortgage costs and liability. 


\section{PBF-609 Special Power Excursion Reactor Test (SPERT) III Reactor Building Waste Experimental Reduction Facility (WERF) Incinerator/RCRA Closure}

Date: $\quad$ July 17,2001

Priority: $\quad$ Ongoing

Scope: $\quad$ This project will affect the "performance-based clean closure" of the WERF incinerators, drum feed/blending unit, and the repackaging unit.

Related Actions : $\quad$ TBD

Location: $\quad$ PBF 609

Point of Contact: $\quad$ F. L. Webber, D\&D\&D Project Manager, 526-8507

Milestones: $\quad$ Startup: 10/01/00 Completion: 9/30/04

Issues: $\quad$ The RCRA closure of the WERF incinerator is quickly becoming a high priority. Cost estimates and schedules will be finalized by 12/6/00 for this project.

Assumptions: $\quad$ See Closure Plan

Cost and Schedule : $\quad \$ 4.71 \mathrm{M}(\mathrm{FY}-02 / 03 / 04)$

Background: $\quad$ The WERF incinerator system, built in a former SPERT reactor facility, was built early 1980s and in hot operation 1984 with its final shutdown 2000.

Justification for Deactivation: Deactivation/closure is necessary to establish and maintain safe and stable facility condition to significantly reduce $S \& M$ liability and cost while awaiting D\&D. 


\section{PBF-616 Storage Building D\&D}

Date: $\quad$ July 17,2001

Priority: $\quad 33$

Scope: $\quad$ Decontaminate and dismantle for potential reuse/recycle.

Related Actions : $\quad$ TBD

Location: $\quad$ PBF 616

Point of Contact: $\quad$ F. L. Webber, D\&D\&D Project Manager, 526-8507

Milestones: $\quad$ Startup: FY-10 Completion: FY-10

Issues: $\quad$ TBD

Assumptions : $\quad$ TBD

Cost and Schedule : $\quad \$ 114 \mathrm{~K}(\mathrm{ROM})$

Background: $\quad$ PBF-616, built in 1962 of steel construction over $820 \mathrm{ft}^{2}$, provided equipment storage involving rad contamination and potentially hazardous chemicals.

Justification for D\&D: D\&D is necessary to eliminate facility hazards and waste streams posing health and safety risks to personnel and the environment. Implementing required mitigations also reduces DOE-ID mortgage costs and liability. 


\section{PBF-617 Storage Building D\&D}

Date: $\quad$ July 17,2001

Priority: $\quad 34$

Scope : $\quad$ Decontamination, demolition, and disposal.

Related Actions : $\quad$ TBD

Location: $\quad$ PBF 617

Point of Contact: $\quad$ F. L. Webber, D\&D\&D Project Manager, 526-8507

Milestones: $\quad$ Startup: FY-10 Completion: FY-10

Issues: $\quad$ TBD

Assumptions : $\quad$ TBD

Cost and Schedule : $\quad \$ 71 \mathrm{~K}(\mathrm{ROM})$

Background: $\quad$ PBF-617, built in 1963 of masonry construction over $370 \mathrm{ft}^{2}$, provided general storage of potentially contaminated items and potentially-hazardous chemicals.

Justification for D\&D: D\&D is necessary to eliminate facility hazards and waste streams posing health and safety risks to personnel and the environment. Implementing required mitigations also reduces DOE-ID mortgage costs and liability. 


\section{PBF-619 Control/Communications Building D\&D}

Date: $\quad$ July 17,2001

Priority: $\quad 26$

Scope: $\quad$ Cleanup and removal of hazardous wastes followed by demolition and disposal.

Related Actions : $\quad$ Removal of SNF from PBF-620.

Location: $\quad$ PBF 619

Point of Contact: $\quad$ F. L. Webber, D\&D\&D Project Manager, 526-8507

Milestones: $\quad$ Startup: FY-08 Completion: FY-08

Issues: $\quad$ TBD

Assumptions : $\quad$ SNF has been removed from PBF-620 reactor facility.

Cost and Schedule : $\quad \$ 806 \mathrm{~K}(\mathrm{ROM})$

Background: $\quad$ PBF-619, built in 1967 of masonry construction over about 5,800 $\mathrm{ft}^{2}$, provided remote operation of the $\mathrm{PBF}$ reactor system.

Justification for D\&D: D\&D is necessary to eliminate facility hazards and waste streams posing health and safety risks to personnel and the environment. Implementing required mitigations also reduces DOE-ID mortgage costs and liability. 


\section{PBF-620 Reactor Canal/MTR-603 Canal Fuel Removal}

Date: $\quad$ July 17,2001

Priority: $\quad 2$

Scope: $\quad$ The SNF that is now in the PBF canal will be repackaged and sent to INTEC for dry storage. This work involves preparation of a safety authorization basis for both PBF and INTEC; fabrication of tooling and buckets; Operational Readiness Review (ORR); approval by DOE to repackage, ship, and store the Power Burst Facility (PBF) spent fuel; repackaging fuel in accordance with approved procedures; transporting fuel to INTEC in an approved transport cask; unloading fuel; and finally storing fuel in a dry storage facility.

Related Actions : $\quad$ Completion of final movements from MTR canal to INTEC

Location: $\quad$ PBF 620

Point of Contact: $\quad$ Doug Toomer, Project Manager, 526-3009

Milestones: $\quad$ Removal of PBF SNF by 9/30/04

Removal of MTR SNF by $9 / 30 / 03$

Issues: $\quad$ None

Assumptions: $\quad$ None

Cost and Schedule : Cost estimate for the combined MTR/PBF fuel removal is $\$ 7.4 \mathrm{M}$.

Background: $\quad$ TBD

Justification for Fuel Removal: Fuel removal is a requirement of the 'Batt Agreement' of 1993;

Settlement Agreement. Fuel in the MTR canal is more degraded than similar fuel stored in the PBF canal. 


\section{PBF-620 PBF Canal Water Removal Deactivation}

Date: $\quad$ July 17,2001

Priority: $\quad 7$

Scope: $\quad$ Removal and disposition of water and non-fuel debris from PBF reactor fuel storage pool.

Related Actions : $\quad$ Fuel removal completed by 9/30/03

Location: $\quad$ Power Burst Facility $(\mathrm{PBF})$ at the INEEL

Point of Contact: $\quad$ J. A. Sherwood, D\&D\&D Project Manager, 526-9369

Milestones: $\quad$ Startup: 10/01/02 Completion: 9/30/08

Issues: $\quad$ No budget planned for FY-07

Assumptions: $\quad$ Fuel removal completed by $9 / 30 / 03$

Cost and Schedule : $\quad$ \$283K (ROM) FY-03 Characterization Planning \$9.6M (ROM) FY-04/08 Removal and Disposition

Background: $\quad$ The canal water provided shielding and moderation during PBF reactor operations.

Justification for Deactivation: The PBF canal contains radiologically contaminated water. Seismic activity could result in a breach of the canal and release of water to the enviroment. 


\section{PBF-620 Reactor Facility Characterization}

Date: $\quad$ July 17,2001

Priority: $\quad 18$ (Delayed/funding shortfall)

Scope : $\quad$ Perform characterization on the PBF in preparation for D\&D.

Related Actions : $\quad$ Milestones: $\quad$ Removal of PBF Reactor Fuel by 9/30/03

Removal of PBF Canal Water by 9/30/08

Location: $\quad$ PBF

Point of Contact: $\quad$ J. A. Sherwood, D\&D\&D Project Manager, 526-9369

Milestones: $\quad$ Baseline $\quad$ Startup: 10/01/07 Completion: TBD

Issues:

- $\quad$ Funding not included to decontaminate, clean, or replace any equipment to be used to perform the work.

\section{Assumptions :}

- $\quad$ Characterization data will primarily be used for determining the means for disposing of D\&D waste and to support developing PBF area end sate scenarios; however, analysis may also be used to satisfy Voluntary Consent Order (VCO) issues.

- A total of 130 locations will be sampled. Forty locations will be sampled for radiological analysis only; and samples form the remaining 90 locations will include a full array of radiological and chemical analysis.

- If sample data and analysis are available from the WAG 6 operable unit characterization, it is assumed the analysis will be suitable for D\&D characterization. Known sample locations with existing analytical results will not be re-sampled.

Cost and Schedule : The $\$ 1.45 \mathrm{M}$ for characterization is proposed to start on 10/01/07 and complete 9/30/10.

Background: $\quad$ The facility is expected to include hazardous waste, rad waste, TSCA waste, and waste streams inherent to the facility construction materials.

Justification for Characterization: Performing characterization early (prior to fuel removal) will allow for timely completion of water removed. It is likely that an EIS will be required for final D\&D of PBF. Early characterization will support all options analysis in the EIS. 


\section{PBF-621 Emergency Generator Building D\&D}

Date: $\quad$ July 17,2001

Priority: $\quad 19$

Scope: $\quad$ Cleanup of potentially-hazardous materials from dried generator operations.

Related Actions: $\quad$ TBD

Location: $\quad$ PBF 621

Point of Contact: $\quad$ F. L. Webber, D\&D\&D Project Manager, 526-8507

Milestones: $\quad$ Startup: FY-09 Completion: FY-09

Issues: $\quad$ TBD

Assumptions: $\quad$ TBD

Cost and Schedule : $\quad \$ 131 \mathrm{~K}(\mathrm{ROM})$

Background: $\quad$ PBF-621, built in 1970 of steel construction over $320 \mathrm{ft}^{2}$, provided emergency power by two generators, to support PBF operations. The facility system is now inactive.

Justification for D\&D: D\&D is necessary to eliminate facility hazards and waste streams posing health and safety risks to personnel and the environment. Implementing required mitigations also reduces DOE-ID mortgage costs and liability. 


\section{PBF-623 WERF Waste Storage Building D\&D}

Date: $\quad$ July 17,2001

Priority: $\quad 30$

Scope: $\quad$ Cleanup of a potentially HW sump and dismantlement for reuse/recycle.

Related Actions : $\quad$ WERF closure

Location: $\quad$ PBF 623

Point of Contact: $\quad$ F. L. Webber, D\&D\&D Project Manager, 526-8507

Milestones: $\quad$ Startup: 10/1/08 $\quad$ Completion: $9 / 30 / 09$

Issues: $\quad$ TBD

Assumptions: $\quad$ TBD

Cost and Schedule : $\quad$ Cost $-\$ 1.7 \mathrm{M}(\mathrm{ROM})$

Background: $\quad$ PBF-623, built in 1991 of prefab steel construction over $9,800 \mathrm{ft}^{2}$, provided both cold and heated storage space with a spill retention area under grating in the heated side.

Justification for D\&D: D\&D is necessary to eliminate facility hazards and waste streams posing health and safety risks to personnel and the environment. Implementing required mitigations also reduces DOE-ID mortgage costs and liability. 


\section{PBF-624 Auxiliary Building D\&D}

Date: $\quad$ July 17,2001

Priority: $\quad 49$

Scope: $\quad$ TBD

Related Actions: $\quad$ Sampling/cleanup of manhole systems; dismantlement for reuse/recycle.

Location: $\quad$ PBF 624

Point of Contact: $\quad$ F. L. Webber, D\&D\&D Project Manager, 526-8507

Milestones: $\quad$ Startup: FY-08 $\quad$ Completion: FY-08

Issues: $\quad$ TBD

Assumptions: $\quad$ TBD

Cost and Schedule : $\quad$ Cost $-\$ 191 \mathrm{~K}(\mathrm{ROM})$

Background: $\quad$ PBF-624, built in 1973 of steel construction over about $190 \mathrm{ft}^{2}$, provided firewater support to its adjoining coating tower structure supporting PBF reactor operations.

Justification for D\&D: D\&D is necessary to eliminate facility hazards and waste streams posing health and safety risks to personnel and the environment. Implementing required mitigations also reduces DOE-ID mortgage costs and liability. 


\section{PBF-625 Maintenance and Storage Building D\&D}

Date: $\quad$ July 17,2001

Priority: $\quad 20$

Scope: $\quad$ Decontamination and cleanup of minimum hazardous wastes (asbestos, PCBs, $\mathrm{Pb}$ paint); demolition and disposal with same reuse/recycle.

Related Actions: $\quad$ TBD

Location: $\quad$ PBF 625

Point of Contact: $\quad$ F. L. Webber, D\&D\&D Project Manager, 526-8507

Milestones: $\quad$ Startup: FY-08 $\quad$ Completion: FY-09

Issues: $\quad$ TBD

Assumptions: $\quad$ TBD

Cost and Schedule : $\quad \$ 682 \mathrm{~K}(\mathrm{ROM})$

Background: $\quad$ PBF-625, built in 1966 of steel construction over 3,200 $\mathrm{ft}^{2}$, provided materials storage and emergency power to the PBF-620 reactor building. With the generator now on standby, the facility provides materials storage.

Justification for D\&D: D\&D is necessary to eliminate facility hazards and waste streams posing health and safety risks to personnel and the environment. Implementing required mitigations also reduces DOE-ID mortgage costs and liability. 


\section{PBF-627 Gas Cylinder Storage Building D\&D}

Date: $\quad$ July 17,2001

Priority: $\quad 30$

Scope: $\quad$ Cleanup, dismantlement, and disposal with limited reuse/recycle.

Related Actions : $\quad$ TBD

Location: $\quad$ PBF 627

Point of Contact: $\quad$ F. L. Webber, D\&D\&D Project Manager, 526-8507

Milestones: $\quad$ Startup: FY-09 Completion: FY-09

Issues: $\quad$ TBD

Assumptions: $\quad$ TBD

Cost and Schedule : $\quad \$ 129 \mathrm{~K}(\mathrm{ROM})$

Background: $\quad$ The now inactive PBF-627, built in 1966 of steel construction over $130 \mathrm{ft}^{2}$, provided remote safe storage of pressure-bottled gases supporting PBF reactor operations.

Justification for D\&D: D\&D is necessary to eliminate facility hazards and waste streams posing health and safety risks to personnel and the environment. Implementing required mitigations also reduces DOE-ID mortgage costs and liability. 


\section{PBF-629 Stack Gas Monitor Building D\&D}

Date: $\quad$ July 17,2001

Priority: $\quad 31$

Scope: $\quad$ Minimum cleanup and dismantle for reuse/recycle.

Related Actions: $\quad$ TBD

Location: $\quad$ PBF 629

Point of Contact: $\quad$ F. L. Webber, D\&D\&D Project Manager, 526-8507

Milestones: $\quad$ Startup: FY-08 $\quad$ Completion: FY-08

Issues: $\quad$ TBD

Assumptions: $\quad$ TBD

Cost and Schedule : $\quad \$ 90 \mathrm{~K}(\mathrm{ROM})$

Background: $\quad$ The PBF-629 facility, built in 1981 of steel construction over $90 \mathrm{ft}^{2}$, houses a stack-gas monitor system specific to the PBF-620 reactor building stack.

Justification for D\&D: D\&D is necessary to eliminate facility hazards and waste streams posing health and safety risks to personnel and the environment. Implementing required mitigations also reduces DOE-ID mortgage costs and liability. 


\section{PBF-634 Firewater Pump House D\&D}

Date: $\quad$ July 17,2001

Priority: $\quad 36$

Scope: $\quad$ Minimal cleanup of hazardous wastes (asbestos, PCBs, Pb paint); demolition and disposal with limited reuse/recycle.

Related Actions: $\quad$ TBD

Location: $\quad$ PBF 634

Point of Contact: $\quad$ F. L. Webber, D\&D\&D Project Manager, 526-8507

Milestones: $\quad$ Startup: FY-10 Completion: FY-10

Issues: $\quad$ TBD

Assumptions: $\quad$ TBD

Cost and Schedule : $\quad \$ 221 \mathrm{~K}(\mathrm{ROM})$

Background: $\quad$ PBF-634, built in 1983 of steel construction over $750 \mathrm{ft}^{2}$, provides firewater via pump system and adjoining tank, (AST) to the PBF reactor area.

Justification for D\&D: D\&D is necessary to eliminate facility hazards and waste streams posing health and safety risks to personnel and the environment. Implementing required mitigations also reduces DOE-ID mortgage costs and liability. 


\section{PBF-705 Fuel Oil Tank \#2 D\&D}

Date: $\quad$ July 17,2001

Priority: $\quad 35$

Scope: $\quad$ Cleanup of contaminated soils, tank, and pipe; demolition and removal with some reuse potential.

Related Actions: $\quad$ TBD

Location: $\quad$ PBF 705

Point of Contact: $\quad$ F. L. Webber, D\&D\&D Project Manager, 526-8507

Milestones: $\quad$ Startup: 10/1/09 Completion: $9 / 30 / 10$

Issues: $\quad$ TBD

Assumptions : $\quad$ Tank is pumped empty and presents no major spills.

Cost and Schedule : $\quad \$ 112 \mathrm{~K}(\mathrm{ROM})$

Background: $\quad$ PBF-705, installed in 1987 at 4,000 gal, provide fuel (diesel) to various utilities at the PBF reactor area.

Justification for D\&D: D\&D is necessary to eliminate facility hazards and waste streams posing health and safety risks to personnel and the environment. Implementing required mitigations also reduces DOE-ID mortgage costs and liability. 


\section{PBF-709 Fuel Oil Tank D\&D}

Date: $\quad$ July 17,2001

Priority: $\quad 48$

Scope: $\quad$ Soil remediation followed by tank and pipe disconnect and removal with limited reuse/recycle.

Related Actions: $\quad$ TBD

Location: $\quad$ PBF 709

Point of Contact: $\quad$ F. L. Webber, D\&D\&D Project Manager, 526-8507

Milestones: $\quad$ Startup: 10/1/09 Completion: $9 / 30 / 10$

Issues: $\quad$ TBD

Assumptions : $\quad$ Tank is pumped empty and presents no major spills.

Cost and Schedule : $\quad \$ 84 \mathrm{~K}(\mathrm{ROM})$

Background: $\quad$ PBF-709, installed in 1960 as a UST with 3,000 gal, provided fuel oil to various utilities at the PBF reactor area.

Justification for D\&D: D\&D is necessary to eliminate facility hazards and waste streams posing health and safety risks to personnel and the environment. Implementing required mitigations also reduces DOE-ID mortgage costs and liability. 


\section{PBF-719 Substation D\&D}

Date: $\quad$ July 17,2001

Priority: $\quad 47$

Scope: $\quad$ Sampling/PCBs, spill cleanup; demolition and removal with some reuse/recycle.

Related Actions: $\quad$ TBD

Location: $\quad$ PBF 719

Point of Contact: $\quad$ F. L. Webber, D\&D\&D Project Manager, 526-8507

Milestones: $\quad$ Startup: FY-10 Completion: FY-10

Issues: $\quad$ TBD

Assumptions : $\quad$ No major spills of transformer fluid.

Cost and Schedule : $\quad \$ 143 \mathrm{~K}(\mathrm{ROM})$

Background: $\quad$ PBF-719, installed in 1976 with $2,775 \mathrm{kva}$, provides primary power to various utilities in the PBF reactor area.

Justification for D\&D: D\&D is necessary to eliminate facility hazards and waste streams posing health and safety risks to personnel and the environment. Implementing required mitigations also reduces DOE-ID mortgage costs and liability. 


\section{PBF-720 Cooling Tower D\&D}

Date: $\quad$ July 17,2001

Priority: $\quad 46$

Scope: $\quad$ Cleanup of possible hazardous waste; demolition and disposal

Related Actions: $\quad$ TBD

Location: $\quad$ PBF 720

Point of Contact: $\quad$ F. L. Webber, D\&D\&D Project Manager, 526-8507

Milestones: $\quad$ Startup: FY-10 Completion: FY-10

Issues: $\quad$ Potential hazardous waste issue with wood materials and surrounding grounds.

Assumptions: $\quad$ TBD

Cost and Schedule : $\quad \$ 173 \mathrm{~K}(\mathrm{ROM})$

Background: $\quad$ PBF-720, built in 1976 of steel and wood fabrication over a 1,000 $\mathrm{ft}^{2}$ basin, provided a "chill water" cooling system at 11,365 tons/hr, for cooling of PBF reactor secondary coolant.

Justification for D\&D: D\&D is necessary to eliminate facility hazards and waste streams posing health and safety risks to personnel and the environment. Implementing required mitigations also reduces DOE-ID mortgage costs and liability. 


\section{PBF-722 Fuel Oil Storage Tank No. 2 (UST) D\&D}

Date: $\quad$ July 17,2001

Priority: $\quad 45$

Scope: $\quad$ Soil remediation followed by tank and pipe disconnect and removal with limited reuse/recycle.

Related Actions: $\quad$ TBD

Location: $\quad$ PBF 722

Point of Contact: $\quad$ F. L. Webber, D\&D\&D Project Manager, 526-8507

Milestones: $\quad$ Startup: FY-10 Completion: FY-10

Issues: $\quad$ TBD

Assumptions : $\quad$ Tank is pumped empty and presents no major spills.

Cost and Schedule : $\quad \$ 597 \mathrm{~K}(\mathrm{ROM})$

Background: $\quad$ PBF 722, installed in the 1960s as a UST with 10,000 gal, provided fuel oil to various utilities at the $\mathrm{PBF}$ reactor area.

Justification for D\&D: D\&D is necessary to eliminate facility hazards and waste streams posing health and safety risks to personnel and the environment. Implementing required mitigations also reduces DOE-ID mortgage costs and liability. 


\section{PBF-726 Septic Tank D\&D}

Date: $\quad$ July 17,2001

Priority: $\quad 58$

Scope: $\quad$ Abandon in place in accordance with IDAPA 16.01.03.87.23.

Related Actions : $\quad$ TBD

Location: $\quad$ PBF 726

Point of Contact: $\quad$ F. L. Webber, D\&D\&D Project Manager, 526-8507

Milestones: $\quad$ Startup: 10/1/09 Completion: $9 / 30 / 10$

Issues: $\quad$ TBD

Assumptions: $\quad$ No hazardous waste present.

Cost and Schedule : $\quad \$ 25 \mathrm{~K}(\mathrm{ROM})$

Background: $\quad$ PBF-726, installed in 1960 as a UST with 625 gal, provided industrial/sanitary waste collection treatment.

Justification for D\&D: D\&D is necessary to eliminate facility hazards and waste streams posing health and safety risks to personnel and the environment. Implementing required mitigations also reduces DOE-ID mortgage costs and liability. 


\section{PBF-728 Septic Tank D\&D}

Date: $\quad$ July 17,2001

Priority: $\quad 59$

Scope: $\quad$ Abandon in place in accordance with IDAPA 16.01.03.87.23.

Related Actions: $\quad$ TBD

Location: $\quad$ PBF 728

Point of Contact: $\quad$ F. L. Webber, D\&D\&D Project Manager, 526-8507

Milestones: $\quad$ Startup: FY-08 Completion: FY-08

Issues: $\quad$ TBD

Assumptions: $\quad$ No hazardous waste present.

Cost and Schedule : $\quad \$ 85 \mathrm{~K}(\mathrm{ROM})$

Background: $\quad$ PBF-728, installed in 1970 as a UST with 1,000 gal. The sanitary system comprises a 1,000 gal septic tank and a drain field that permits septic tank effluent to percolate through the soil. The system receives waste from the PBF Reactor building and is located northwest of the PBF-620 building. It is listed as a no-action site under CERCLA.

Justification for D\&D: D\&D is necessary to eliminate facility hazards and waste streams posing health and safety risks to personnel and the environment. Implementing required mitigations also reduces DOE-ID mortgage costs and liability. 


\section{PBF-730 Primary Water Storage Tank D\&D}

Date: $\quad$ July 17,2001

Priority: $\quad 44$

Scope: $\quad$ Drain, decontaminate, demolition, and remove with some reuse/recycle.

Related Actions : $\quad$ TBD

Location: $\quad$ PBF 730

Point of Contact: $\quad$ F. L. Webber, D\&D\&D Project Manager, 526-8507

Milestones: $\quad$ Startup: FY-10 Completion: FY-10

Issues: $\quad$ TBD

Assumptions: $\quad$ No hazardous waste present.

Cost and Schedule : $\quad \$ 478 \mathrm{~K}(\mathrm{ROM})$

Background: $\quad$ PBF-730, installed in 1976 as an AST with 14,000 gal, supported water supply system to PBF reactor area.

Justification for D\&D: D\&D is necessary to eliminate facility hazards and waste streams posing health and safety risks to personnel and the environment. Implementing required mitigations also reduces DOE-ID mortgage costs and liability. 


\section{PBF-731 Corrosive Waste Disposal Sump D\&D}

Date: $\quad$ July 17,2001

Priority: $\quad 60$

Scope: $\quad$ Sample, cleanup, disposal, demolition removal and disposal.

Related Actions : $\quad$ TBD

Location: $\quad$ PBF 731

Point of Contact: $\quad$ F. L. Webber, D\&D\&D Project Manager, 526-8507

Milestones: $\quad$ Startup: FY-10 Completion: FY-10

Issues: $\quad$ TBD

Assumptions: $\quad$ Involves various hazardous wastes.

Cost and Schedule: $\quad \$ 65 \mathrm{~K}(\mathrm{ROM})$

Background: $\quad$ PBF-731, built in 1972 with a 863 CFT capacity over $21 \mathrm{ft}^{2}$, is an inclined concrete sump structure effluent to the sump (1972-1984) included chromium contaminated water from the PBF Reactor sec. coolant loop, resins, sulfuric acid, and sulfuric dioxide. Post 1984 no chromium discharge to the sump.

Justification for D\&D: D\&D is necessary to eliminate facility hazards and waste streams posing health and safety risks to personnel and the environment. Implementing required mitigations also reduces DOE-ID mortgage costs and liability. 


\section{PBF-732 Hot Waste Storage Tank D\&D}

Date: $\quad$ July 17,2001

Priority: $\quad 37$

Scope: $\quad$ Sampling, waste determination, spill cleanup, decontamination, demolition, and disposal.

Related Actions: $\quad$ TBD

Location: $\quad$ PBF 723

Point of Contact: $\quad$ F. L. Webber, D\&D\&D Project Manager, 526-8507

Milestones: $\quad$ Startup: FY-10 Completion: FY-10

Issues: $\quad$ May involve various hazardous/mixed wastes.

Assumptions: $\quad$ Isolated; pumped empty, no major spills.

Cost and Schedule : $\quad$ \$597K (ROM)

Background: $\quad$ PBF-732, installed 1978 as a UST with 10,000 gal, provides storage of contaminated wastes from PBF reactor operations.

Justification for D\&D: D\&D is necessary to eliminate facility hazards and waste streams posing health and safety risks to personnel and the environment. Implementing required mitigations also reduces DOE-ID mortgage costs and liability. 


\section{PBF-734 Fire \& Domestic Water Storage Tank D\&D}

Date: $\quad$ July 17,2001

Priority: $\quad 43$

Scope: $\quad$ Drain, demolish and dispose with some reuse/recycle.

Related Actions : $\quad$ TBD

Location: $\quad$ PBF 734

Point of Contact: $\quad$ F. L. Webber, D\&D\&D Project Manager, 526-8507

Milestones: $\quad$ Startup: FY-09 Completion: TBD

Issues: $\quad$ TBD

Assumptions : $\quad$ Drained empty and disconnected. No hazardous waste present.

Cost and Schedule : $\quad \$ 2.1 \mathrm{M}(\mathrm{ROM})$

Background: $\quad$ PBF-734, installed in 1984 as an AST with 280,000 gal, supported potable water and firewater supply system to the PBF reactor area.

Justification for D\&D: D\&D is necessary to eliminate facility hazards and waste streams posing health and safety risks to personnel and the environment. Implementing required mitigations also reduces DOE-ID mortgage costs and liability. 


\section{PBF-761 Spray Dryer Absorber Structural Support D\&D}

Date: $\quad$ July 17,2001

Priority: $\quad 56$

Scope: $\quad$ Decontamination if required, dismantle, and remove with some reuse/recycle.

Related Actions : $\quad$ D\&D of PBF-609.

Location: $\quad$ PBF 761

Point of Contact: $\quad$ F. L. Webber, D\&D\&D Project Manager, 526-8507

Milestones: $\quad$ Startup: 10/1/09 Completion: 9/30/10

Issues: $\quad$ TBD

Assumptions: $\quad$ No hazardous/rad waste present.

Cost and Schedule : $\quad \$ 200 \mathrm{~K}(\mathrm{ROM})$

Background: $\quad$ The PBF-761 Spray Dryer Absorber, built in 1990, covering about 2,000 $\mathrm{ft}^{2}$; was built as a replacement for the HX and baghouse on the WERF incinerator. However, this system was never connected to the incinerator off-gas and therefore never operated.

Justification for D\&D: D\&D is necessary to eliminate facility hazards and waste streams posing health and safety risks to personnel and the environment. Implementing required mitigations also reduces DOE-ID mortgage costs and liability. 


\section{TAN-602 Administration Building D\&D}

Date: $\quad$ July 17,2001

Priority: $\quad$ TBD (characterization planned for FY-03)

Scope: $\quad$ Complete site characterization and project development in support of an asbestos abatement followed by demolition and disposal followed by project closeout.

Related Actions: $\quad$ TBD

Location: $\quad$ Test Area North

Point of Contact: $\quad$ F. L. Webber, D\&D\&D Project Manager, 526-8507

Milestones: $\quad$ Characterization $\quad$ Startup: $10 / 1 / 02$

Fieldwork Completion: 9/30/04

Issues: $\quad$ The TAN-602 gatehouse and its adjoining telephone dialroom are not part of the planned D\&D.

Assumptions: $\quad$ Timely project approval and funding authorization

Cost and Schedule : $\quad$ Characterization $\quad$ FY-03 $\quad \$ 530 \mathrm{~K}$

D\&D FY-04 \$1.34M

Background: $\quad$ The TAN-602 facility is a 1-story structure of masonry construction at about $48,000 \mathrm{ft}^{2}$ built in 1954 and inactivated 1995. It supported project personnel in engineering and administrative activities.

Justification for D\&D: D\&D is necessary to eliminate facility hazards and waste streams posing health and safety risks to personnel and the environment. Implementing the D\&D reduces DOE-ID mortgage costs and liability. 


\section{TAN-607, -734 Hot Shop Exhaust D\&D}

Date: $\quad$ July 17,2001

Priority: $\quad 38$

Scope: $\quad$ Sampling, waste determination, decontamination, demolition, and disposal.

Related Actions: $\quad$ TAN-607 Hot Shop Pool Deactivation.

Location: $\quad$ Test Area North (TAN) 734

Point of Contact: $\quad$ F. L. Webber, D\&D\&D Project Manager, 526-8507

Milestones: $\quad$ Startup: $10 / 1 / 07$ Completion: $9 / 30 / 12$

Issues: $\quad$ TBD

Assumptions: $\quad$ Diverse hazardous wastes, mixed waste, and rad waste present. This facility is considered historically significant.

Cost and Schedule : $\quad \$ 23 \mathrm{M}(\mathrm{ROM})$

Background: $\quad$ The TAN-607, built in 1954 of steel and heavily reinforced concrete over $150,701 \mathrm{ft}^{2}$, provided a manufacturing and assembly area, a large hot-shop (hot cell) for disassembly of contaminated reactor experiments, and office space for support personnel. Included in the project will be an exhaust stack/system TAN-734.

Justification for D\&D: D\&D is necessary to eliminate facility hazards and waste streams posing health and safety risks to personnel and the environment. Implementing required mitigations also reduces DOE-ID mortgage costs and liability. 


\section{TAN-607 Hot Shop Pool Deactivation}

Date: $\quad$ July 17,2001

Priority: $\quad 8$

Scope : $\quad$ Waste and sludge removal/disposal, equipment removal, decontamination, and pool stabilization by backfill and grout encapsulation.

Related Actions : $\quad$ Removal of TMI fuel and debris by end of FY-01. Removal of other fuel by the end of FY-03.

Location: $\quad$ TAN-607

Point of Contact: $\quad$ F. L. Webber, D\&D\&D Project Manager, 526-8507

Milestones: $\quad$ Startup: FY-06 Completion: FY-08

Issues: $\quad$ With MTR and PBF canals requiring deactivation in FY-03 through FY-05, funds for TAN-607 may be stretched thin.

Assumptions: $\quad$ Stored SNF materials removed.

Cost and Schedule : $\quad \$ 3.9 \mathrm{M}(\mathrm{ROM})$

Background: $\quad$ The hot shop pool at about 750,000 gal, provides safe storage for experimental SNF and SNF material/debris, since 1954.

Justification for Deactivation: A large volume of radiologically contaminated water is contained in the pool. A seismic event control result in a release to the environment. The removal of fuel from TAN-607 is the last mission for TAN. Closure of all of TAN should begin in FY-04. 


\section{TAN-608 Water Filtration Building D\&D}

Date: $\quad$ July 17,2001

Priority: $\quad 27$

Scope: $\quad$ Sampling waste determination, decontamination, demolition, and disposal.

Related Actions : $\quad$ TAN-607 Hot Shop Pool Deactivation

Location: $\quad$ TAN 608

Point of Contact: $\quad$ F. L. Webber, D\&D\&D Project Manager, 526-8507

Milestones: $\quad$ Startup: FY-08 $\quad$ Completion: FY-08

Issues: $\quad$ TBD

Assumptions: $\quad$ TBD

Cost and Schedule : $\quad \$ 94 \mathrm{~K}(\mathrm{ROM})$

Background: $\quad$ TAN-608, built in 1954 of masonry construction over $334 \mathrm{ft}^{2}$, provides a waterfiltration (shimmer system) system for the TAN-607 Hot Shop Pool.

Justification for D\&D: D\&D is necessary to eliminate facility hazards and waste streams posing health and safety risks to personnel and the environment. Implementing required mitigations also reduces DOE-ID mortgage costs and liability. 


\section{TAN-609 Equipment Maintenance Shop D\&D}

Date: $\quad$ July 17,2001

Priority: $\quad 27$

Scope: $\quad$ Characterization, decontamination, demolition, and disposal

Related Actions : $\quad$ TBD

Location: $\quad$ Test Area North

Point of Contact: $\quad$ F. L. Webber, D\&D\&D Project Manager, 526-8507

Milestones: $\quad$ Startup: FY-04 Completion: FY-05

Issues: $\quad$ TBD

Assumptions: $\quad$ TBD

Cost and Schedule : $\quad \$ 1.24 \mathrm{M}(\mathrm{ROM})$ replanned for FY-04/05:

$\begin{array}{lll}\text { Characterization } & \text { FY-04 } & \$ 491 \mathrm{~K} \\ \text { D\&D } & \text { FY-05 } & \$ 749 \mathrm{~K}\end{array}$

Background: $\quad$ TBD

Justification for D\&D: D\&D is necessary to eliminate facility hazards and waste streams posing health and safety risks to personnel and the environment. Implementing required mitigations also reduces DOE-ID mortgage costs and liability. 


\section{TAN-615 Assembly \& Maintenance Facility D\&D}

Date: $\quad$ July 17,2001

Priority: $\quad$ TBD

Scope: $\quad$ Complete site characterization and project development in support of fieldwork (demolition and disposal) followed by project closeout.

Related Actions: $\quad$ TBD

Location: $\quad$ Test Area North

Point of Contact: $\quad$ F. L. Webber, D\&D\&D Project Manager, 526-8507

Milestones: $\quad$ Characterization $\quad$ Startup: FY-02

Fieldwork Completion: FY-03

Issues: $\quad$ The TAN-615 structure physically limits access to the 'V-Tanks' in the adjoining TAN-616 facility, which is now undergoing remediation.

Assumptions: $\quad$ Timely project approval and funding authorization by DOE-ID.

Cost and Schedule: $\quad$ Characterization $\quad$ FY-02

D\&D FY-03 \$968K

Background: $\quad$ The TAN-615 facility is a two-story steel structure of 4,200 square feet built in 1976. It supports assembly and maintenance activities on radiologically contaminated experimental equipment.

Justification for Characterization: $\quad D \& D$ is necessary to eliminate facility hazards and waste streams posing health and safety risks to personnel and the environment, and to facilitate access to TAN-616. Implementing the D\&D reduces DOE-ID mortgage costs and liability. 


\section{TAN-616 Liquid Waste Treatment Facility Characterization}

Date:

Priority:

Scope :

$\underline{\text { Related Actions : }}$

Location:

Point of Contact:

Milestones:

Issues:

Assumptions :

Cost and Schedule :

Background:
July 17, 2001

\section{7}

The TAN-616 facility characterization specifically addresses the building, including the contaminated floors and walls, the pump room, evaporator pit, and waste process piping associated with the TAN-616 system. A Field Sampling Plan and a Hazardous Waste Determination are the major part of this characterization effort.

None

Within the Test Support Facility Area of TAN

Donna Nicklaus, Project Engineer, 526-5683

Startup: 4/17/00 Completion: 7/31/01

If, during D\&D of the piping feeding the TAN-616 system contaminated soils are discovered, the soils would have to be addressed under a separate new site identification form. The investigation-derived waste (IDW) from sampling activities may become orphan waste due to its listed (F001) and rad level mixed waste character. This characterization will require integration with VCO-IDHW performance requirements to ensure full compliance regarding scope and schedule.

None

The total cost of the characterization is estimated at $\$ 500 \mathrm{~K}$ under VCO funding.

The TAN-616 facility is a single-story reinforced concrete structure made operational 1958. The treatment system was shut down in 1970 due to system failures and resulting releases to the environment. The inactive facility/system has undergone system monitoring and limited surveillance and maintenance since 1970.

Justification for Characterization: Characterization is necessary due to the presence of radiological contamination and hazardous constituents (both listed and mixed waste) within the inactive, shut down facility. Waste characterization will be necessary to identify required mitigation of the hazards. 


\section{TAN-616 Liquid Waste Treatment Facility D\&D/RCRA Closure}

Date: $\quad$ July 17, 2001

Priority: $\quad 9$

Scope : $\quad$ TAN-616 system is listed as a VCO and WAG 1 Action. The proposed recommendation outlined in the VCO is to remove the TAN-616 system and applicable components listed in this scope.

The list below contains the D\&D/closure components of the TAN-616 systems, vessels, and ancillary equipment to be removed as part of this action:

- $\quad$ Tanks V-5, V-6, V-7, V-8, and V-11 and the ancillary system

- $\quad$ The piping from TAN-616 to the PM2A tanks and injection well

- $\quad$ Process waste evaporate system and its interconnecting components

- $\quad$ Process waste piping system and its interconnected components

- $\quad$ Samples not being managed by Comprehensive Environmental Response, Compensation, and Liability Act (CERCLA) from previous characterization efforts (1980 to 1994) that are being stored in a temporary accumulation area (TAA).

Related Actions: $\quad$ Characterization ongoing as project \#7

Location: $\quad$ Within the Test Support Facility area of TAN

Point of Contact: $\quad$ Donna Nicklaus, Project Engineer, 526-5683

Milestones: $\quad$ Startup: 10/01/01 Completion: 09/30/06

Issues: $\quad$ At this time, the VCO has not been signed by the Idaho Department of Health and Welfare (IDHW). There is the potential that the proposed schedule and scope of this action will change. If it is changed, the cost estimate will also change to reflect the new scope and schedule. Also legacy waste and decontamination waste will be listed (F001) mixed waste with rad levels potentially precluding storage or disposal.

Assumptions: $\quad$ None

Cost and Schedule : The cost of the project is estimated at $\$ 13.5 \mathrm{M} / \mathrm{VCO}$ (ROM)

Background: $\quad$ The TAN-616 facility is a single-story reinforced concrete structure made operational 1958. The treatment system was shut down in 1970 due to system failures and resulting releases to the environment. The inactive facility/system has undergone system monitoring and limited surveillance and maintenance since 1970. 
Justification for D\&D/RCRA Closure : $\quad$ D\&D and RCRA closure are necessary due to the presence of radiological contamination and hazardous constituents (both listed and mixed waste) within the inactive, shut down facility/system. Mitigations are necessary to eliminate the facility hazards and waste streams posing health and safety risks to personnel and the environment . 


\section{TAN-633 Hot Cell Annex Deactivation}

Date: $\quad$ July 17,2001

Priority: $\quad 62$

Scope: $\quad$ Sampling, waste determination, decontamination, demolition, and disposal.

Related Actions: $\quad$ TAN-607 Hot Shop Deactivation

TAN-608 Water Filtration Building D\&D

Location: $\quad$ TAN 633

Point of Contact: $\quad$ F. L. Webber, D\&D\&D Project Manager, 526-8507

Milestones: $\quad$ Startup: FY-08 Completion: FY-08

Issues: $\quad$ TBD

Assumptions : $\quad$ TBD

Cost and Schedule : $\quad$ \$219K (ROM)

Background: $\quad$ TAN-633, built in 1954 of heavily reinforced concrete over 3,300 $\mathrm{ft}^{2}$, provided hot cell support to various nuclear experimental operations. The now inactive facility adjoins the TAN-607 Hot Shop and the TAN-607 Hot Shop Pool facilities.

Justification for Deactivation: Deactivation is necessary to establish and maintain safe and stable facility conditions to significantly reduce $S \& M$ liability and cost while awaiting D\&D. 


\section{TAN-633 Hot Cell Annex D\&D}

Date: $\quad$ July 17,2001

Priority: $\quad 27$

Scope:

Related Actions : $\quad$ Completion of the deactivation project

Location: $\quad$ TAN 633

Point of Contact: $\quad$ F. L. Webber, D\&D\&D Project Manager, 526-8507

Milestones: $\quad$ Startup: FY-08 Completion: FY-08

Issues: $\quad$ TBD

Assumptions: $\quad$ TBD

Cost and Schedule : $\quad$ Estimated Cost $-\$ 2.2 \mathrm{M}(\mathrm{ROM})$

Background: $\quad$ TAN-608, built in 1954 of heavily reinforced concrete over 3,300 $\mathrm{ft}^{2}$, provided hot cell support to various nuclear experimental operations. The now inactive adjoins the TAN-607 Hot Shop and the TAN-607 Hot Shop Pool facilities.

Justification for D\&D: D\&D is necessary to eliminate facility hazards and waste streams posing health and safety risks to personnel and the environment. Implementing required mitigations also reduces DOE-ID mortgage costs and liability. 


\section{TAN-649 Water Filtration Building D\&D}

Date: $\quad$ July 17,2001

Priority: $\quad 27$

Scope: $\quad$ Sampling, waste determination, decontamination, demolition, and disposal.

Related Actions : $\quad$ TBD

Location: $\quad$ TAN 649

Point of Contact: $\quad$ F. L. Webber, D\&D\&D Project Manager, 526-8507

Milestones: $\quad$ Startup: FY-08 $\quad$ Completion: FY-08

Issues: $\quad$ TBD

Assumptions: $\quad$ TBD

Cost and Schedule: $\quad \$ 102 \mathrm{~K}(\mathrm{ROM})$

Background: $\quad$ TAN-649, built in 1960 of masonry construction over $210 \mathrm{ft}^{2}$, provided water filtration services to TAN operations.

Justification for D\&D: D\&D is necessary to eliminate facility hazards and waste streams posing health and safety risks to personnel and the environment. Imple menting required mitigations also reduces DOE-ID mortgage costs and liability. 


\section{TAN-650/624 LOFT Characterization}

Date: $\quad$ July 17, 2001

Priority: $\quad 21$

Scope: $\quad$ The focus of the LOFT Characterization Project is to evaluate the current condition of the LOFT facility and identify those items and areas that need to be characterized. Piping, tanks, valves, and other building components identified will be subsequently characterized by sample analysis.

Related Actions: $\quad$ Following characterization, the facility will be scheduled for D\&D.

Location: $\quad$ TAN

Point of Contact: $\quad$ F. L. Webber, D\&D\&D Project Manager, 526-8507

Milestones: $\quad$ Startup: TAN-650 FY-06 Completion: FY-06

Startup: TAN-624 FY-07 Completion: FY-07

Issues:

Assumptions: $\quad$ None

Cost and Schedule : The estimated costs (ROM) for LOFT Characterization is $\$ 1.0 \mathrm{M}$.

Background: $\quad$ TAN-650, built in 1973 of steel and reinforced concrete, includes the containment vessel for the LOFT Reactor system as a mobile test assembly (MTA). TAN-624, built in 1956 of steel construction over 3,000 $\mathrm{ft}^{2}$ was later attached to the LOFT containment vessel of the MTA door.

Justification for Characterization: Characterization is necessary to define facility hazards and waste streams posing health and safety risks to personnel and the environment. Characterization will be necessary to identify required mitigation of the hazards. 


\section{TAN-650/624 Containment Building (Loss-of-Fluid Test [LOFT] Facility) D\&D}

Date: $\quad$ July 17, 2001

Priority: $\quad 57$

Scope : $\quad$ Decontamination, demolition, disposal with of below-grade structures.

Related Actions : $\quad$ TBD

Location: $\quad$ TAN 650/624

Point of Contact: $\quad$ F. L. Webber, D\&D\&D Project Manager, 526-8507

Milestones: $\quad$ Startup: FY-10 Completion: TBD

Issues: $\quad$ Not funded FY-03

Assumptions: $\quad$ TBD

Cost and Schedule : $\quad \$ 1.12 \mathrm{M}(\mathrm{ROM})$

Background: $\quad$ TAN-650, built in 1973 of steel and reinforced concrete includes the containment vessel for the LOFT Reactor system as a mobile test assembly (MTA). TAN-624, built in 1956 of steel construction over 3,000 $\mathrm{ft}^{2}$, was later attached to the LOFT Containment Vessel at the MTA Door.

Justification for D\&D: D\&D is necessary to eliminate facility hazards and waste streams posing health and safety risks to personnel and the environment. Implementing required mitigations also reduces DOE-ID mortgage costs and liability. 


\section{TAN 662 Gas Cylinder Storage Building D\&D}

Date: $\quad$ July 17,2001

Priority: $\quad 36$

Scope: $\quad$ TBD

Related Actions : $\quad$ TBD

Location: $\quad$ Test Area North (TAN)

Point of Contact: $\quad$ F. L. Webber, D\&D\&D Project Manager, 526-8507

Milestones: $\quad$ Startup: FY-10 Completion: FY-10

Issues: $\quad$ TBD

Assumptions : $\quad$ No hazardous waste present, and no major spills or discharges.

Cost and Schedule : $\quad \$ 708 \mathrm{~K}(\mathrm{ROM})$

Background: $\quad$ TAN-662, built in 1978 of steel construction over about $300 \mathrm{ft}^{2}$, provides safe storage for gas cylinders (pressurized) and some petroleum products.

Justification for D\&D: D\&D is necessary to eliminate facility hazards and waste streams posing health and safety risks to personnel and the environment. Implementing required mitigations also reduces DOE-ID mortgage costs and liability. 


\section{TAN-726 - Liquid Waste Storage Tank Building D\&D}

Date: $\quad$ July 17,2001

Priority: $\quad 28$

Scope: $\quad$ Sampling, waste determination, decontamination, demolition, and disposal.

Related Actions : $\quad$ TBD

Location: $\quad$ TAN 726

Point of Contact: $\quad$ F. L. Webber, D\&D\&D Project Manager, 526-8507

Milestones: $\quad$ Startup: FY-08 Completion: FY-09

Issues: $\quad$ TBD

Assumptions : $\quad$ Pumped empty; no major spills.

Cost and Schedule : $\quad \$ 3.1 \mathrm{M}(\mathrm{ROM})$

Background: $\quad$ TAN-726, built in 1975 as a steel UST at 100,000 gal in a concrete vault, provided collection and containment of rad waste resultant of TAN operations.

Justification for D\&D: D\&D is necessary to eliminate facility hazards and waste streams posing health and safety risks to personnel and the environment. Implementing required mitigations also reduces DOE-ID mortgage costs and liability. 


\section{TRA-603 Material Test Reactor Canal Fuel Removal}

Date: $\quad$ July 17,2001

Priority: $\quad 1$

Scope: $\quad$ The SNF materials now stored in the MTR canal and plug storage holes 1 and 2 will be repackaged and sent to INTEC for dry storage. This work involves preparation of a safety authorization basis for both MTR and INTEC; fabrication of tooling and buckets; ORR; approval by DOE to repackage, ship, and store the SNF materials; repackaging fuel in accordance with approved procedures; transporting fuel to INTEC in an approved transport cask; unloading fuel; drying fuel; and finally storing fuel in a dry storage facility.

Related Actions: $\quad$ None

Location: $\quad$ MTR Canal at TRA 603

Point of Contact: $\quad$ Doug Toomer, Project Manager, 526-3009

Milestones: $\quad$ Removal of SNF stored in the MTR Canal by 9/30/03

Issues: $\quad$ Structural integrity of fuel is an unknown. Critically safety evaluation at INTEC is an issue because of epoxy and excess water issues.

Assumptions: $\quad$ Fuel repackaging remains ahead of schedule.

Cost and Schedule : Cost estimate for the MTR canal fuel removal is included in the $\$ 7.4 \mathrm{M}$ (ROM) life cycle cost for PBF Canal fuel removal; page 25.

Background: $\quad$ The MTR Canal involves about 120,000 gal of water for safe storage of SNF materials.

Justification for Fuel Removal: $\quad$ Removal of fuel is a requirement of the 'Batt Agreement' of 1993; Spent Fuel Settlement Agreement. Fuel in the MTR is highly degraded and must be re-canned. 


\section{TRA-603 MTR Canal Water Removal Deactivation}

Date: $\quad$ July 17,2001

Priority: $\quad 6$

Scope: $\quad$ After the fuel is removed, water that is now in the MTR canal will be pumped to the TRA evaporation ponds, sampled, and analyzed. After the water is removed, the canal will be decontaminated to prevent the spread of airborne contamination until final D\&D of the MTR building.

Related Actions : $\quad$ Completion of SNF Removal by 9/30/02

Location: $\quad$ MTR Canal at TRA 603

Point of Contact: $\quad$ F. L. Webber, D\&D\&D Project Manager, 526-8507

Milestones: $\quad$ Startup: FY-03 Completion: FY-07

Issues: $\quad$ It is unknown at this time whether TRA will accept the water into the evaporation ponds. Discussions have started but cannot be finalized until analysis of the water is completed. Because FY-02 funding was cut, this project will finish in FY-05. The risk of an additional two years is minimal.

Assumptions: $\quad$ TBD

Cost and Schedule: Cost estimate for the MTR canal water removal is $\$ 2.6 \mathrm{M}(\mathrm{ROM})$ life cycle. Characterization of debris in the canal was initiated in January 2000.

Background: Water removal will involve about 120,000 gal of contaminated water.

The canal in the reactor building basement is considered an integral part of the overall facility design. The canal, which is located in the MTR basement, is $8 \mathrm{ft}$ wide, $15.5 \mathrm{ft}$ below floor level, and extends $121.5 \mathrm{ft}$ eastward from the reactor structure. The reactor buildings east wall is $40 \mathrm{ft}$ from the reactor structure; therefore, the canal extends $81.5 \mathrm{ft}$ beyond the reactor building east wall. Outside the reactor building, the canal has a $6 \mathrm{ft}$ wide working space on each side and at the east end. This working space is enclosed by a tunnel $13 \mathrm{ft} 8 \mathrm{in}$. high and $21 \mathrm{ft}$ wide.

A "rabbit canal" lies directly west of the reactor structure and is $6 \mathrm{ft}$ wide $\times 6 \mathrm{ft}$ deep $\times 18.5 \mathrm{ft}$ long. A $7 \mathrm{ft}$ wide portion of the canal below the subpile room and reactor structure connects the rabbit canal and main canal. This section, as well as the rabbit canal, has been drained of all water and sealed off. A permanent bulkhead was installed to isolate it from the remainder of the main canal. A cover and shielding has been placed over this section to protect personnel.

Justification for Water Removal: The MTR canal contains radiologically contaminated water. A seisamic event could result in a release to the environment. 


\section{TRA-603 Material Test Reactor Canal D\&D}

Date: $\quad$ July 17, 2001

Priority: $\quad 6$

Scope: $\quad$ Decontamination, backfill, grout stabilization/entombment.

Related Actions : $\quad$ Completion of waste removal deactivation.

Location: $\quad$ TRA 603

Point of Contact: $\quad$ F. L. Webber, D\&D\&D Project Manager, 526-8507

Milestones: $\quad$ Startup: FY-05 Completion: FY-05

Issues: $\quad$ TBD

Assumptions : $\quad$ TBD

Cost and Schedule: $\quad \$ 567 \mathrm{~K}(\mathrm{ROM})$

Background: $\quad$ The oldest of the INEL Test Reactors, the Materials Test Reactor (MTR), is located at the Test Reactor Area (TRA) and was first operated in 1952. The MTR logged just under 180,000 MW-days and more than 19,000 neutron irradiations before retirement in August 1970 and partial dismantling and decommissioning in 1974.

In 1980, water used for additional shielding was drained from the reactor vessel after external radiation levels indicated it was no longer required.

The MTR-603 main floor has been used as a valve operation and remote maintenance mockup area since 1976. The main reactor overhead 50 ton crane is extensively used for loading and unloading casks from trucks. The portion of the main floor not used for valve testing provides access for trucks as well as for cask and other experimental equipment storage.

The MTR Water Canal, formerly the Test Train Assembly Facility (TTAF), is located in the basement of the MTR building.

The east end of the MTR water canal is connected to the ARMF canal by a $5.1 \mathrm{~cm}$ shuttle tube, which was inactivated in 1983. Spent fuel, irradiated samples, and associated equipment are still stored in the canal. The canal in the reactor building basement is considered an integral part of the overall facility design. The canal, which is located in the MTR basement, is $8 \mathrm{ft}$ wide, $15.5 \mathrm{ft}$ below floor level, and extends $121.5 \mathrm{ft}$ eastward from the reactor structure. The reactor building east wall is $40 \mathrm{ft}$ from the reactor structure; therefore, the canal extends $81.5 \mathrm{ft}$ beyond the reactor building east wall. Outside the reactor building, the canal has a $6 \mathrm{ft}$ wide working space on each side and at the east end. This working space is enclosed by a tunnel $13 \mathrm{ft} 8 \mathrm{in}$. high and $21 \mathrm{ft}$ wide. 
Justification for D\&D: D\&D is necessary to eliminate facility hazards and waste streams posing health and safety risks to personnel and the environment. Implementing required mitigations also reduces DOE-ID mortgage costs and liability. 


\section{TRA-642 Engineering Test Reactor (ETR) Facility D\&D}

Date:

Priority:

Scope:

$\underline{\text { Related Actions : }}$

Location:

Point of Contact:

Milestones:

Issues:

Assumptions :

Cost and Schedule :

Background:
July 17, 2001

22

Characterization

TBD

TRA 642

F. L. Webber, D\&D\&D Project manager, 526-8507

Startup: FY-08 Completion: FY-16 (ROM)

Funding support.

TBD

$\$ 20.2 \mathrm{M}(\mathrm{ROM})$

The Engineering Test Reactor (ETR) first operated in 1957. The ETR evolved from the demand for high flux testing space, more stable flux, and greater variety of flux levels than the MTR could provide, and the need for through-the-core facilities. Fuel, coolant, and moderator characteristics were studied in environments similar to those that would exist in many types of reactors. The 175 MW ETR could provide neutron fluences averaging 3-5 $\times 10^{15} \mathrm{n} / \mathrm{cm}^{2}$.

In 1972, the ETR was modified for a new role to support DOE's breeder reactor safety program. Test programs relating to reactor core design and operation were performed by means of the Sodium Loop Safety Facility (SLSF) inserted in the ETR core. The water loop programs were terminated in 1975. As a test vehicle supporting DOE breeder rector safety programs, the reactor was modified with a new top closure accommodating the irradiation loop in 1975. Other modifications included adding a helium coolant system and sodium-handling system.

From 1975 to 1981, self-contained sodium (liquid-metal) loops supported a national safety program. The sodium in the loops was removed and the system flushed during ETR deactivation. ETR was deactivated and radiologically characterized in 1982 (EGG-PR-5784).

The reactor building is $136 \mathrm{ft}$ by $112 \mathrm{ft}$ and extends $58 \mathrm{ft}$ above grade and $38 \mathrm{ft}$ below grade to the basement floor. The walls, floors, and columns below grade are reinforced concrete. The walls above grade are insulated metal siding with the interior surface sealed and taped to make the structure gastight. The roof was reworked in 1982 and consists of steel decking covered with light weight concrete, asphalt, felt vapor retardant, another layer of asphalt, a layer of $3 / 4 \mathrm{in}$. fiberboard and $3 \mathrm{in}$. of urethane foam, $3 / 4 \mathrm{in}$. fiberboard covered with fiberglass felt and two layers of asphalt and gravel. The panel walls, roof, and crane structure are supported on a steel superstructure of columns and trusses. The steel 
columns rest on reinforced concrete columns, which extend to bedrock from the first floor level.

The first basement level, or console floor, housed all experimental control panels. The second basement level contained all radioactive experimental equipment in shielded concrete cubicles. The reactor pressure vessel is about $35 \mathrm{ft}$ long and $12 \mathrm{ft}$ in diameter at the top, with a lower section diameter of $8 \mathrm{ft}$. It has a cluster of perforations in the bottom head to accommodate the control rod drives and experimental loop through-piping. The reactor top is approximately $7 \mathrm{ft} 10 \mathrm{in}$. above the main floor level. The high pressure experimental water loops and nonregenerable-resin bypass demineralizers to control water quality. In general, the water loop radioactivity level was approximately that of the primary coolant $\left(10^{5} \mathrm{dpm} / \mathrm{ml}\right)$. Each loop could be drained to either the warm or hot drain system.

Justification for D\&D: Due to the relatively large size of this reactor and facility, characterization is required before reasonable cost estimates can be produced. It is likely that an EIS will be required for the $\mathrm{D} \& \mathrm{D}$ of the facility. 


\section{TRA-643 Compressor Building D\&D}

Date: $\quad$ July 17,2001

Priority: $\quad 39$

Scope: $\quad$ Characterization, decontamination, demolition, and disposal.

Related Actions : $\quad$ TBD

Location: $\quad$ TRA 643

Point of Contact: $\quad$ F. L. Webber, D\&D\&D Project Manager, 526-8507

Milestones: $\quad$ Startup: FY-08 Completion: FY-10

Issues: $\quad$ Funding support.

Assumptions: $\quad$ This will be performed as part of the ETR D\&D

Cost and Schedule : $\quad \$ 3.1 \mathrm{M}(\mathrm{ROM})$

Background: $\quad$ TRA-643 housed the equipment used to supply heated, hydrocarbon-free air to various experiments. The process control room controlled all plant services and a sample laboratory conducted chemistry samples on the primary and secondary coolant systems. TRA-643 is $125 \mathrm{ft}$ by $30.5 \mathrm{ft}$ high. The primary coolant system (PCS) pump pits extend $10 \mathrm{ft} 3 \mathrm{in}$. below the floor, and $21 \mathrm{ft} 6 \mathrm{in}$. from the wall. A plywood barrier separates the contaminated storage items from the noncontaminated items.

The above grade walls are 12 in. pumice block to a height of $8 \mathrm{ft}$ with insulated metal panels above. The north wall contains $4 \mathrm{ft}$ high manually operated metal louvers for a $52 \mathrm{ft}$ long section just above the pumice block, which have been covered with aluminum sheets. The foundation is a spread-footing type supported by pipe piling. Floors are concrete, with asphalt tile covering the control room only. Much of the flooring contains a grating-covered trench extending as far as $8 \mathrm{ft}$ below the floor. The compressor building roof is steel deck on steel frame, vapor-sealed, with 2 in. of glass insulation. The roofing is built-up with a gravel top and is surrounded by a $1 \mathrm{ft}$ parapet. The process control room walls are constructed of 4-in. pumice blocks with 3 in. of glass fiber insulation between. The balcony has an $11 \mathrm{in}$. concrete floor and contains three motor control centers. A 7.5 ton overhead crane with top running trolley, has a lift of $27 \mathrm{ft}$, span of $40 \mathrm{ft}$ 2 in., and spread of $7 \mathrm{ft}$. The rail is $20 \mathrm{ft}$ above the floor and has $100 \mathrm{ft}$ runway. The main floor is served with 20 drains that drain to a sump the pumps to the cold waste leaching pond.

Justification for D\&D: D\&D is necessary to eliminate facility hazards and waste streams posing health and safety risks to personnel and the environment. Implementing required mitigations also reduces DOE-ID mortgage costs and liability. 


\section{TRA-644 ETR Heat Exchanger Building D\&D}

Date: $\quad$ July 17, 2001

Priority: $\quad 40$

Scope: $\quad$ Characterization, decontamination, demolition, and disposal.

Related Actions : $\quad$ TBD

Location: $\quad$ TRA 644

Point of Contact: $\quad$ F. L. Webber, D\&D\&D Project manager, 526-8507

Milestones: $\quad$ Startup: FY-08 $\quad$ Completion: FY-10

Issues: $\quad$ Funding support.

Assumptions: $\quad$ This will be performed as part of the ETR D\&D

Cost and Schedule : $\quad \$ 2.6 \mathrm{M}(\mathrm{ROM})$

Background: $\quad$ TRA-644 includes: (a) main room and lower level, (b) demineralizer wing (valve room and tank room), (c) degassing tank room, (d) cubicle exhaust booster blower room, and (e) secondary pipe pit. The primary function of the main room was to house the 12 primary to secondary heat exchanges and piping. The $26 \mathrm{ft}$ long by $4 \mathrm{ft}$ diameter heat exchangers each contain 1,700 5/8 in. OD tubes.

TRA-644 is constructed of reinforced concrete; the west wall is $5 \mathrm{ft}$ thick, the east wall $4 \mathrm{ft}$ thick, and the north and south wall are $4 \mathrm{ft} 6$ in. thick. The building is $66.5 \mathrm{ft}$ by $78 \mathrm{ft}$ by $22 \mathrm{ft}$ high above ground. The lower level on the 3 north side extends down an additional $17 \mathrm{ft} 9$ in. below grade. The roof is $3 \mathrm{ft}$ thick reinforced concrete. The west wall rests on the east wall of the reactor building and connects on the north to the compressor building. Four knockout wall sections are provided on the south wall for removal of the heat exchanger banks. The knockout sections are high density shielding block. The building was ventilated by an exhaust fan installed on the building roof that discharged to the exhaust stack through the cubicle exhaust piping. The automatic heat exchanger vents, primary piping and pumps drained to the warm drains. The heat exchangers and associated piping are drained.

Justification for D\&D: D\&D is necessary to eliminate facility hazards and waste streams posing health and safety risks to personnel and the environment. Implementing required mitigations also reduces DOE-ID mortgage costs and liability. 


\section{TRA-648 ETR Electrical Building D\&D}

Date: $\quad$ July 17,2001

Priority: $\quad 17$

Scope: $\quad$ Characterization, decontamination, demolition, and disposal.

Related Actions: $\quad$ TBD

Location: $\quad$ TRA 648

Point of Contact: $\quad$ F. L. Webber, D\&D\&D Project Manager, 526-8507

Milestones: $\quad$ Startup: FY-05 Completion: FY-06

Issues: $\quad$ Funding support.

Assumptions: $\quad$ This will be performed as part of the ETR D\&D

Cost and Schedule : $\quad \$ 964 \mathrm{~K}(\mathrm{ROM})$

Background: $\quad$ TRA-648 consists of the 13.8-KV, 4,160 V, and $480 \mathrm{~V}$ switchgear, No. 1 diesel generator, five motor-generator units, and one lead-storage battery bank. The building is a two-level structure consisting of the upper level and a basement level referred to as the cable vault. The upper level is structural steel frame, $54 \mathrm{ft}$ by $115 \mathrm{ft}$ by $16.5 \mathrm{ft}$ high. The north wall is common with the ETR reactor building (TRA-642) south wall and is metal panel installed on a steel frame. The exterior walls are 12 in. pumice block. The floor, basement walls, and basement slab are reinforced concrete. Footings are spread-type supported by pipe piling. The roof is steel deck on steel frame, insulated, vapor sealed, built-up, and topped with gravel There are five rooms within the upper level; the No. 1 battery room, No. 2 battery room, No. 1 diesel generator room, the motor-generator room and the switchgear room. All water systems in the building have been drained. The $\mathrm{CO}_{2}$ fire protection system was left in service to provide fire protection to the building. The dry pipe firewater valve supplies fire protection systems in the cable vault, the reactor building low-bay, and the diesel engine rooms.

The No. 1 battery room is $17 \mathrm{ft} 10 \mathrm{in}$. by $21 \mathrm{ft} 4 \mathrm{in}$. The No. 2 battery room is $17 \mathrm{ft} 10 \mathrm{in}$. by $14 \mathrm{ft}$. The walls are $8 \mathrm{in}$. pumice block. No. 1 battery room has four monorails and a 0.5 ton trolley. The room contains 120 lead acid battery cells. The battery has been left in service and connected to the motor-generated switchgear units. No. 2 battery room has had the battery bank removed and is used for archiving of ETR records. A demineralized water line supplies both battery rooms. The $\mathrm{CO}_{2}$ fire protection lines supply the battery rooms, motor-generator room, switchgear room, and cable vault.

Justification for D\&D: D\&D is necessary to eliminate facility hazards and waste streams posing health and safety risks to personnel and the environment. Implementing required mitigations also reduces DOE-ID mortgage costs and liability. 


\section{TRA-660 Advanced Reactivity Measurement Facility (ARMF) Decommissioning}

Date:

Priority:

Scope :

\section{$\underline{\text { Related Actions : }}$}

Location:

Point of Contact:

Milestones:

Issues:

Assumptions :

Cost and Schedule:

Background:
July 17, 2001

5 (Ongoing)

Decontamination of the TRA-660 facility, started in October 1999, will include removal of remaining RCRA hazardous materials (lead and cadmium) and radiologically contaminated materials and equipment. This will include the reactor housings, platforms, neutron radiography system, irradiated experimental capsules, sump pump, piping, and a pneumatic transfer system. Clean materials and equipment to be removed include the reactor control consoles, an interior 2story office structure, and electrical components associated with power for the reactors. Additional radiological characterization of the irradiated experimental capsules is planned for February of 2001 utilizing an underwater gamma spectroscopy system.

At completion of the removal of the radiologically contaminated equipment and materials from the canal, the canal water is planned for disposal in the TRA Evaporation Pond. The canal and sump will be decontaminated and backfilled with clean fill material. The concrete parapet around the canal will be cut flush with the main floor. With the completion of the decontamination activities (FY 2001), the facility will be transferred back to the TRA Facility Landlord organization for reuse.

None

TRA

G. R. Rodman, D\&D\&D Project Task Lead, 533-4314

Startup: FY $1999 \quad$ Completion: 9/30/01

Characterization of the irradiated experimental capsules for disposal may require a subcontract with offsite contractor for use of an underwater gamma spectroscopy system.

Completion of this project has been replanned from 3/26/02 back to 9/30/01 due to FY-02 funding shortfalls.

None

The estimated decontamination and decommissioning cost for TRA-660 is \$3.02M to cover work started in FY 1998 and completion of the project in FY 2001.

TRA-660, known as the Advanced Reactivity Measurement Facility (ARMF) and the Coupled Fast Reactivity Measurement Facility (CFRMF) was constructed in 1959 to house improved reactivity measurement reactor designs. The $40-\mathrm{ft}$ by $60-$ $\mathrm{ft}$ masonry building houses a $28 \times 8 \times 18 \mathrm{ft}$ deep concrete canal with two light- 
water moderated reactors (ARMF and CFRMF). A neutron radiography facility is also located in the approximate center of the canal. A 15-ton overhead crane with a 1-ton hoist spans the floor and canal areas. The reactors have not been operated since 1991 and were defueled in 1997.

Justification for Decommissioning: The canal contained 30,000 gallons of radiologically contaminated water, and in turn contained highly activated reactor components. Following disposition of the irradiated experimental capsules remaining in the canal, will be disposal of the remaining 1,500 gallons of water, and completion of the decommissioning as planned. 


\section{TRA-663 Superior Diesel Building D\&D}

Date: $\quad$ July 17,2001

Priority: $\quad 32$

Scope: $\quad$ Characterization, decontamination, demolition, and disposal.

Related Actions : $\quad$ TBD

Location: $\quad$ TRA 663

Point of Contact: $\quad$ F. L. Webber, D\&D\&D Project Manager, 526-8507

Milestones: $\quad$ Startup: FY-06 $\quad$ Completion: FY-06

Issues: $\quad$ Funding support.

Assumptions: $\quad$ TBD

Cost and Schedule : $\quad$ \$198K (ROM)

Background: $\quad$ A second diesel generator was added to ETR, allowing one to be off-line for maintenance while the other generator was operated. The No. 2 diesel building housed the No. 2 diesel generator, a starting air compressor, air receiver tank, lubricating oil and jacket water coolers, a lubricating oil filter, motor control center (MCC-4A), and space heating units. TRA- 633 is $53.5 \mathrm{ft}$ by $19 \mathrm{ft}$ by $20 \mathrm{ft}$ high. The north wall is common with the ETR electrical building south wall. All walls are 12 in. cinder block. The floor is 6 in. thick concrete. The roof was reworked in 1982 and consists of steel decking covered with concrete, asphalt, felt vapor retardant, asphalt, $3 / 4$ in. fiberboard, 3 in. urethane foam, 3/4 in. fiberboard, fiberglass felt, and two layers of asphalt and gravel.

Two large fans on the roof served as the ventilation system. Each vertical fan duct is $52 \mathrm{in}$. in diameter and is covered by a louver that opens via airflow. An abandoned steam heating unit is suspended form the ceiling. An overhead monorail carries a manually operated 4,000 lb chain fall and passes over the diesel. Diesel fuel oil was supplied by a day tank buried outside. The diesel engine lubricating oil and jacket water were cooled by UCW. Demineralized water supplied the jacket water expansion tank. Fire water supplies the dry pipe system sprinkler. Steam lines supplying the space heater were abandoned 1980. The diesel engine rests on a concrete pad $13 \mathrm{ft}$ by $6 \mathrm{ft}$ by $18 \mathrm{in}$. above floor level and extends $6 \mathrm{ft}$ below floor level. The generator is in a $55 \mathrm{in}$. deep pit. The engine was mothballed in place in 1982. The lubricating oil system was treated with preservative and the oil pumped out. The jacket water was drained, as have been the oil filter, oil cooler, and jacket water cooler. The starting air receivers have been drained and power to the compressor has been interrupted. The generator and exciter have been covered with plastic sheeting. 
Justification for D\&D: D\&D is necessary to eliminate facility hazards and waste streams posing health and safety risks to personnel and the environment. Implementing required mitigations also reduces DOE-ID mortgage costs and liability. 


\section{TRA-704 ETR Primary Filter Pits Characterization}

Date:

Priority:

Scope :

Related Actions :

Location:

Point of Contact:

Milestones:

Issues:

Assumptions :

Cost and Schedule :

Background:
July 17,2001

14

The scope of work for D\&D of the filter pits is only in the conceptual planning stage because characterization is not yet completed. For planning purposes, it was assumed that the majority of the piping in the two tunnels and the TRA-706 delay tanks and enclosures would be left in place. It was also assumed that the asbestos lagging on the three experimental loop piping runs in the north General Electric Experimental Loop (GEEL) tunnel would be left in place and contained by sealing the ends of the tunnel. The filters contained in the TRA-704 (primary filter pit) and TRA-705 (secondary filter pit) would be removed and sent to TAN-607 for disassembly, sampling, and disposal. The filter pits would be decontaminated and backfilled with clean material. The TRA-755 hot filters would be removed and the pits decontaminated and backfilled with clean material. The TRA-755 hot filters would be removed and the pits decontaminated and backfilled. The remainder of TRA-755 would be left in place until TRA-642 reactor building undergoes D\&D because the cubic le exhaust from the reactor building is routed through TRA-755. Approximately $420 \mathrm{ft}$ of 20 -in. diameter air waste piping from TRA-755 to its present termination would also be dismantled and disposed. The sumps in TRA- 655 would be decontaminated, the above grade concrete structure dismantled, and the basement backfilled to grade.

Planning of D\&D is subject to completion of characterization.

TRA 704/705/706/755/655

\section{F. L. Webber, D\&D\&D Project Manager, 526-8507}

Startup: FY-07 Completion: FY-08

The D\&D cost estimate at $\$ 1.06 \mathrm{M}$, is based on numerous assumptions that may or may not be accurate. If the TRA-706 delay tanks and enclosures are required to be removed rather than left in place, D\&D costs will greatly increase. The same is true if the piping cannot be left in the north GEEL tunnel.

See Scope

The estimated characterization cost in \$1.06M (ROM). The estimated planning costs for D\&D of these structures are $\$ 1.07 \mathrm{M}$ based on the above assumptions. It is estimated it will require three years to complete this work once funding is available.

Completed in 1957, the TRA-642 ETR provided additional irradiation space and extended material testing conditions. The exhaust piping for the ETR is routed from the reactor building through underground tunnels, pits with filters, and delay tanks to the ETR waste gas stack. These originally consisted of the north GEEL accessible tunnel, the TRA-755 hot filter pits containing three separate loop filters, and TRA-755. The GEEL modification (circa 1960) added an 
additional pipe tunnel which is not accessible, Primary Filter Pit (TRA-704), Secondary Filter Pit (TRA-705) containing two filters each and two Delay Tanks (TRA-706). In addition to the radioactive air effluents that were routed through the north GEEL tunnel, there are hot and warm liquid waste lines from tanks located in the reactor building basement going to the TRA-713 hot storage tanks. TRA-655 was originally built as a filter building and air intake for an experimental air system, which included two large air compressors in TRA-643. The filters have been removed and the building has been used as a storage building.

Justification for Characterization: To define and eliminate facility hazards and waste streams posing health and safety risks to personnel exposure and release to the environment. Facilitates and elimination of mitigation required to eliminate risks. 


\section{TRA-704 Primary Filter Pits D\&D}

Date: $\quad$ July 17, 2001

Priority: $\quad 41$

Scope: $\quad$ The scope of work for D\&D of the filter pits is only in the conceptual planning stage due the characterization not being completed. For planning purposes it was assumed that the majority of the piping in the two tunnels and the TRA-706 Delay Tanks and enclosures would be left in place. It was also assumed that the asbestos lagging on the three experimental loop piping runs in the north GEEL tunnel would be left in place and contained by sealing the ends of the tunnel. The filters contained in the TRA-704 (Primary Filter Pit) and TRA-705 (Secondary Filter Pit) would be removed and sent to TAN-607 for disassembly, sampling, and disposal. The filter pits would be decontaminated and backfilled with clean material. The TRA-755 hot filters would be removed and the pits decontaminated and backfilled. The remainder of TRA-755 would be left in place until TRA-642 Reactor Building under goes D\&D as the cubicle exhaust from the reactor building is routed through TRA-755. Approximately $420 \mathrm{ft}$. of 20-in. diameter air waste piping from TRA-755 to its present termination would also be dismantled and disposed. The sumps in TRA- 655 would be decontaminated, the above grade concrete structure dismantled, and the basement backfilled to grade.

Related Actions: $\quad$ Planning of D\&D is subject to completion of characterization.

Location:

Point of Contact:

Milestones:

Issues:

Assumptions :

Cost and Schedule :

Background:

\section{TRA 704/705/706/755/655}

\section{F. L. Webber, D\&D\&D Project Manager, 526-8507}

Startup: FY-08 Completion: FY-08

The $\mathrm{D} \& \mathrm{D}$ cost estimate $(\$ 1.07 \mathrm{M})$ is based on numerous assumptions that may or may not be accurate. If the TRA-706 Delay Tanks and enclosures are required to be removed rather than left in place, D\&D costs will be greatly increased. The same is true if the piping cannot be left in the north GEEL tunnel. The scope for D\&D of the TRA-655 Air Intake Building may be performed as a separate task.

See Scope

The estimated cost for D\&D of these structures is $\$ 1.07 \mathrm{M}$ (ROM) based on the above assumptions. It is estimated it will require three years to complete this work once funding is available.

Completed in 1957, the TRA-642 Engineering Test Reactor (ETR) provided additional irradiation space and extended material testing conditions. The exhaust piping for the ETR reactor is routed from the reactor building through underground tunnels, pits with filters, and delay tanks to the ETR waste gas stack. These originally consisted of the north General Electric Experimental Loop (GEEL) accessible tunnel, the TRA-755 hot filter pits containing three separate loop filters, and TRA-755. The GEEL modification (circa 1960) added an additional pipe tunnel which is not accessible, Primary Filter Pit (TRA-704), 
Secondary Filter Pit (TRA-705) containing two filters each and two Delay Tanks (TRA-706). In addition to the radioactive air effluents that were routed through the north GEEL tunnel, there are hot and warm liquid waste lines from tanks located in the reactor building basement going to the tRA-713 hot storage tanks. TRA-655 was originally built as a filter building and air intake for an experimental air system, which included tow large air compressors in TRA-643. The filters have been removed and the building has been used as a storage building.

Justification for D\&D: To eliminate facility hazards and waste streams piping health and safety risks to personnel exposure and release to the environment. To implement required mitigations thus reducing DOE-ID mortgage costs and liability. 


\section{TRA-712 Retention Basin (Ungrd) D\&D}

Date: $\quad$ July 17,2001

Priority: $\quad 42$

Scope: $\quad$ Characterization, decontamination, demolition, and disposal.

Related Actions: $\quad$ TBD

Location: $\quad$ TRA 712

Point of Contact: $\quad$ F. L. Webber, D\&D\&D Project Manager, 526-8507

Milestones: $\quad$ Startup: FY-10 Completion: FY-10

Issues: $\quad$ TBD

Assumptions: $\quad$ TBD

Cost and Schedule : $\quad \$ 1.2 \mathrm{M}(\mathrm{ROM})$

Background: $\quad$ The retention basin is located about $150 \mathrm{ft}$ directly south of the MTR fan house and consists of two underground rectangular concrete tanks. Each tank is $130 \mathrm{ft}$ long by $20 \mathrm{ft}$ wide by $20 \mathrm{ft}$ deep, separated by a $1 \mathrm{ft}$ thick common concrete wall. A serpentine flow path is created through the tanks by use of $1 \mathrm{ft}$ thick concrete baffles across the width of each tank at $10 \mathrm{ft}$ intervals. Six baffles hang from the roof and 5 alternate baffles stand on the basin floor.

Justification for D\&D: D\&D is necessary to eliminate facility hazards and waste streams posing health and safety risks to personnel and the environment. Implementing required mitigations also reduces DOE-ID mortgage costs and liability. 


\section{TRA-730-A, B, C, D Catch Tanks \#1, 2, 3, 4 Deactivation (UnGrd Hot Waste)}

Date: $\quad$ July 17, 2001

Priority: $\quad 66,67,68,69$

Scope : $\quad$ Characterization, decontamination, demolition, and disposal.

Related Actions: $\quad$ TBD

Location: $\quad$ TRA 730

Point of Contact: $\quad$ F. L. Webber, D\&D\&D Project Manager, 526-8507

Milestones: $\quad$ Startup: FY-10 Completion: TBD

Issues: $\quad$ TBD

Assumptions : $\quad$ TBD

Cost and Schedule : $\quad$ Estimated Cost $\quad 14.8 \mathrm{~K} \quad$ FY-10

TBD/ FY-11

Background: $\quad$ These tanks are located to the south of the MTR-630 Catch Tank Pump Pit. They are $7.5 \mathrm{ft}$ underground and are labeled 309-A, B, C, and D. They are mounted on steel frames on a concrete slab that is $15 \mathrm{ft}$ below grade. Centrally located on the slab are natural drainage sumps and a dry well that extends $1 \mathrm{ft}$ above grade. The four black-iron glass lined tanks are 1,500 gal capacity. Two catch tanks receive water from the laboratories and selected building drains. The other two catch tanks receive water from the TRA hot cells. While one of the tanks is receiving water from its source, the other is either in a standby condition or is being sampled for radioactivity in preparation for pumping.

Justification for Deactivation: Deactivation is necessary to establish and maintain safe and stable facility conditions to significantly reduce $S \& M$ liability and cost while awaiting D\&D. Such underground systems possess more direct pathways for release to the environment. 


\section{TRA-752 ETR Transformer Yard D\&D}

Date: $\quad$ July 17,2001

Priority: $\quad 29$

Scope: $\quad$ Characterization, decontamination, demolition, and disposal.

Related Actions : $\quad$ TBD

Location: $\quad$ TRA 752

Point of Contact: $\quad$ F. L. Webber, D\&D\&D Project Manager, 526-8507

Milestones: $\quad$ Startup: FY-08 $\quad$ Completion: FY-09

Issues: $\quad$ TBD

Assumptions: $\quad$ TBD

Cost and Schedule : $\quad \$ 473 \mathrm{~K}(\mathrm{ROM})$

Background: $\quad$ The transformer station provides power to the ETR complex. The yard is a locked exclusion area. The ten transformers are identified at T-1, T-2, T-3, T-4, T-5, T-7, T-8, T-9, T-11, and HT-1. T-6 was removed in 1980, a new concrete pad was installed and HT-1 was placed on the pad. HT-1 provides power for the electrical resistance heaters throughout ETR. Two sets of resistors are located in cages and were used for ground detection on T-1 and T-2. The transformer station is $110 \mathrm{ft}$ by $33.5 \mathrm{ft}$. The east fence is corrugated asbestos on an iron frame. The north boundary is common to the No. 2 diesel building the remaining boundary is cyclone type fence. The floor is 6 in. gravel base. Concrete pillars or pads of various dimensions bear transformer weight and provide cable ways for the underground cable runs to the cable vault. The transformers are isolated from each other by asbestos fence or fire walls. All transformers, except HT-1, were dielectric tested for the presence of polychlorinated biphenyl (PCB) and are placarded per 44 CFR 106. HT-1 was manufactured November 1979, after the ban on PCB usage went into effect. Each transformer, except T-9, has lees than 50 ppm PCBs and is classified as PCB free. T-9 indicated a PCB content between 50 and 499 ppm and is classified as PCB contaminated.

Justification for D\&D: D\&D is necessary to eliminate facility hazards and waste streams posing health and safety risks to personnel and the environment. Implementing required mitigations also reduces DOE-ID mortgage costs and liability. 


\section{TRA-753 ETR Exhaust Stack D\&D}

Date: $\quad$ July 17,2001

Priority: $\quad 23$

Scope: $\quad$ Characterization, decontamination, demolition, and disposal.

Related Actions : $\quad$ TBD

Location: $\quad$ TRA 753

Point of Contact: $\quad$ F. L. Webber, D\&D\&D Project Manager, 526-8507

Milestones: $\quad$ Startup: FY-08 $\quad$ Completion: FY-09

Issues: $\quad$ TBD

Assumptions : $\quad$ TBD

Cost and Schedule : $\quad \$ 2.9 \mathrm{M}(\mathrm{ROM})$

Background: $\quad$ The $250 \mathrm{ft}$ vertical stack is a tapered reinforced concrete tube with an outside diameter of $14 \mathrm{ft}$ at the base and $6 \mathrm{ft}$ at the top and an inside diameter of $10 \mathrm{ft}$ at the bottom and $5 \mathrm{ft}$ at the top. A concrete block gas monitoring room, at the base of the stack, is $9 \mathrm{ft}$ by $10 \mathrm{ft}$ by $8 \mathrm{ft}$ high and has a 4 in. thick concrete floor. All monitoring equipment has been removed.

Justification for D\&D: D\&D is necessary to eliminate facility hazards and waste streams posing health and safety risks to personnel and the environment. Implementing required mitigations also reduces DOE-ID mortgage costs and liability. 


\section{Annual INEEL S\&M-Non Defense Programs}

Date: $\quad$ July 17,2001

Priority: $\quad$ Annual Activity

Scope: $\quad$ S\&M of non-defense buildings throughout the INEEL. S\&M includes repairs as necessary, upkeep of utility systems as necessary, surveillance of systems, and configuration management.

Related Actions : $\quad$ Fuel removal from MTR and PBF canals.

Location: $\quad$ Various

Point of Contact: $\quad$ C. R. Posegate, Project Supervisor, 526-6784

Milestones: $\quad$ N/A

Issues: $\quad$ There is not sufficient non-defense funds at INEEL in FY-02 to maintain compliance.

Assumptions : $\quad$ Portions of the SOW will be paid with defense funds.

Cost and Schedule: $\quad$ The activity is budgeted at $\$ 1.3 \mathrm{M}$ for FY-02. Schedule is ongoing.

Background: $\quad$ TBD

Justification for S\&M: S\&M is required to minimize risk and liability associated with releases/discharges from inactive facilities, both contaminated and noncontaminated, while awaiting D\&D. 


\section{Inactive Sites Project Surveillance and Maintenance Program}

\section{Scope}

The purpose of the Inactive Sites S\&M Program is to provide a consistent application of surveillance activities to facilities across the INEEL. These activities include performance of facility inspections using multidisciplinary personnel to document building/structure conditions, to assist in resolution of discovered issues within the scope of the program, and to provide feedback to the responsible facility manager $(\mathrm{FM})$.

The S\&M program is an integral section of the Environmental Restoration Program. The S\&M program provides a centralized focus for transitioning facilities from an active state, maintaining the facility in an environmental and safety-compliant baseline during the inactive state, and finally to facility disposition or D\&D.

The S\&M inspections will be performed by a team of personnel knowledgeable in general safety, environmental compliance, and budget planning and oversight. Since the inactive facilities are not frequently occupied, personnel performing the general safety inspections will be those with a good working, operational knowledge of industrial safety and hygiene. Each facility inspection shall include a competent person possessing an environmental compliance background to ensure environmental issues are confidently identified, documented, and proper resolution initiated.

\section{End Objective for the Project}

The Inactive Sites S\&M Program does not fit the strict definition of a project in that there is no specified end state; rather, it is an ongoing long-term program. The program was established to provide a central point of responsibility for performing S\&M activities on inactive/deactivated facilities and structures throughout the INEEL. Additionally, a significant aspect of the program is to identify, document, and resolve those conditions that are environmentally non-compliant and pose risks to personnel health and safety. The extent of resolution to such issues is contingent upon approved fiscal spending by both the inactive sites' S\&M budget and the individual facility's budget. Attainment of these objectives is expected to result in a reduction in the number and extent of audit/surveillance findings and infractions of applicable requirements and laws, and a reduction in levied fines.

In the future, any facility that will be placed on the list of inactive sites must adhere to a specific set of criteria prior to being accepted into the program. These criteria are defined in MCP-3480, Environmental Instructions for Facilities, Processes, Materials, and Equipment, and are designed to ensure compliance with applicable environmental and safety requirements. Once in the program, facilities will be maintained in an environmental and safety-compliant condition and vital equipment maintained functionally sound to prevent significant deterioration. Further activities involving the facility will be the responsibility of the program responsible for the next phase of the facility's life cycle (e.g., D\&D or facility owner for a reestablished use).

\section{Excluded Work}

As previously stated, the extent of issue resolution is limited due to the constraints on available funding. Therefore, characterization of unknown chemicals is outside the scope of the Inactive Sites S\&M Program. If discovered, these conditions will be documented in the program's database and the responsible FM will be notified of the discovery. It is the FM's responsibility to pursue further activities (e.g., notifications, sampling and characterization analyses, proper interim storage, or disposition). The Inactive Sites S\&M Program database will serve as a living document for identification of such issues. 
Additionally, the Inactive Sites S\&M Program will identify vital equipment maintenance needs, communicate them to the FM, and initiate the appropriate Work Control Form if requested by the manager. The FM has the responsibility for follow-on actions and development/approval of any maintenance activity.

\section{Project Deliverables}

Principle objectives of the program include application of consistent surveillance activities and identification and documentation of environmental non-compliance and hazardous waste issues. Resolution of these conditions and achievement and maintenance of an environmentally-compliant baseline are proportional to the extent of fiscal funding. However, the program will deliver a reduction in the number of non-compliance issues and provide a vehicle for early preparation for D\&D activities (e.g., hazard identification and materials issues).

Additional program deliverables include the initiation/facilitation of identified corrective maintenance to maintain a facility's vital equipment as a result of periodic monitoring of facility conditions. This monitoring will be performed at specified frequencies based on a graded approach. Surveillance includes a comparison of previous and current conditions to ascertain changes in facility condition and content therein. A database that includes relevant facility information (e.g., facility condition, materials stored in the facility, identified non-compliance conditions, resolution to these issues, etc.) will be established and maintained. This database also serves is as an information source for early planning activities associated with D\&D work.

The affected FM shall receive a copy of the inspection reports. These reports show any issues discovered during the inspections, the proposed resolution to discovered issues, and completion of corrective actions as well as miscellaneous facility condition/status information for future use.

\section{Project Constraints}

One of the principle objectives of the Inactive Sites S\&M Program is to identify, document, and resolve non-compliance issues as they relate to the environment and personnel safety. Limitations relative to resolution of these identified issues exist. Program funding does not support corrective actions for $100 \%$ of the identified issues. Some issues will require significant effort and funding that is outside the scope of this program and possibly outside the budgetary constraints of the facility's cost control account. However, it is still vital to document these issues and maintain this documentation. This documentation shows awareness of the issue; can be used for application of a graded approach to future corrective actions, input for budgetary planning, or $\mathrm{D} \& \mathrm{D}$; and allows for safety management of future personnel entries.

While the Inactive Sites S\&M Program will be responsible for resolving issues that are simple-tomoderate in nature, significant non-compliance issues (e.g., characterization of unknown solutions/materials discovered during $S \& M$ activities) remain the responsibility of the facility manager.

The FM has the final approval for activities within their structures. As a result of numerous variables, this approval may not be granted for all corrective actions.

\section{Project Interfaces}

The Inactive Sites S\&M Program does not have facility ownership. This ownership resides with a variety of FMs for which inactive sites personnel provide S\&M functions. Therefore, significant interfacing is required to accomplish program goals. Since the Inactive Sites S\&M Program has a limited 
core group of personnel, it will rely heavily on working within each site area's established organizational structure. These technical resources include personnel from organizations such as radiological controls, environmental engineering, waste generator services, industrial hygiene and safety, and maintenance.

The design of the program strengthens the role of the FM. Inactive sites personnel perform the S\&M duties for these facilities and, with the approval of the FM, utilize the site area's support personnel to accomplish the various objectives. In this regard, surveillance is performed at set intervals using various technical experts to identify and resolve non-compliance issues in a consistent, focused, costeffective manner.

\section{Inactive Sites Project Surveillance and Maintenance (S\&M)}

Date:

Priority:

Scope:

$\underline{\text { Related Actions : }}$

Location:

Point of Contact:

Milestones:

Issues:

Assumptions:

Cost and Schedule : $\quad$ Estimated Cost $-\$ 2.29 \mathrm{M} / \mathrm{FY}-02$

Background:

July 17, 2001

Ongoing

TBD

Site-wide

Ongoing constraints.

None

TBD
Provide S\&M of 176 inactive facilities.

C. R. Posegate, Project Supervisor, 526-6784

The addition of 66 inactive facilities is expected for FY-02 pending funding

Justification for S\&M: S\&M is required to minimize risk and liability associated with releases/discharges from inactive facilities, both contaminated and non-contaminated, while awaiting D\&D. 


\section{REFERENCES}

Batt Agreement of 1993, Spent Fuel Settle Agreement, page 24.

Detailed Work Plan for Decontamination and Decommissioning (ID-ER-11; INEEL/EXT-2001-00480), page 1.

DOE 430.1A Life Cycle Asset Management, page 1. 